\title{
Enhanced Component Performance Study: Air-Operated Valves 1998-2012
}

\author{
T. E. Wierman
}

October 2013

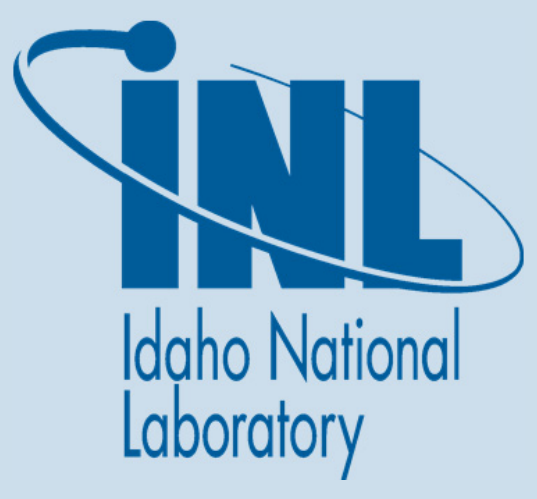

The INL is a U.S. Department of Energy National Laboratory operated by Battelle Energy Alliance 
NOTICE

This information was prepared as an account of work sponsored by an agency of the U.S. Government. Neither the U.S. Government nor any agency thereof, nor any of their employees, makes any warranty, express or implied, or assumes any legal liability or responsibility for any third party's use, or the results of such use, of any information, apparatus, product, or process disclosed herein, or represents that its use by such third party would not infringe privately owned rights. The views expressed herein are not necessarily those of the U.S. Nuclear Regulatory Commission. 


\title{
Enhanced Component Performance Study: Air-Operated Valves 1998-2012
}

\author{
T. E. Wierman
}

October 2013

Update Completed September 2013

Idaho National Laboratory

Risk Assessment and Management Services Department Idaho Falls, Idaho 83415

\author{
Prepared for the \\ Division of Risk Assessment \\ Office of Nuclear Regulatory Research \\ U.S. Nuclear Regulatory Commission \\ Washington, D.C. 20555 \\ Job Code N6631
}






\begin{abstract}
This report presents an enhanced performance evaluation of air-operated valves (AOVs) at U.S. commercial nuclear power plants. The data used in this study are based on the operating experience failure reports from fiscal year 1998 through 2012 for the component reliability as reported in the Equipment Performance and Information Exchange (EPIX). Results (beta distributions for failure probabilities upon demand and gamma distributions for rates) are used as inputs to the U.S. Nuclear Regulatory Commission standardized plant analysis risk models of U.S. commercial nuclear power plants. The AOV failure modes considered are failure-to-open/close, failure to operate or control, and spurious operation. The component reliability estimates and the reliability data are trended for the most recent 10-year period while yearly estimates for reliability are provided for the entire active period. No statistically significant increasing trends were identified in the AOV results. Statistically significant decreasing trends were identified in two areas: AOV operation demands less than or equal to 20 demands per year and greater than 20 demands.
\end{abstract}




\section{CONTENTS}

ABSTRACT iv

ACRONYMS $\mathrm{x}$

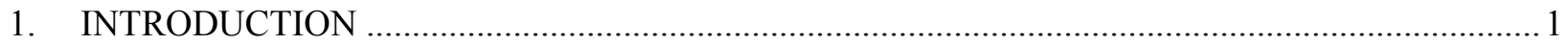

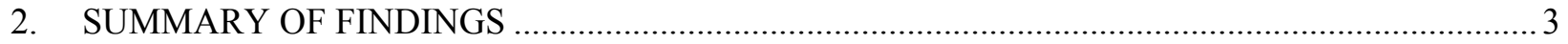

3. FAILURE PROBABILITIES AND FAILURE RATES …

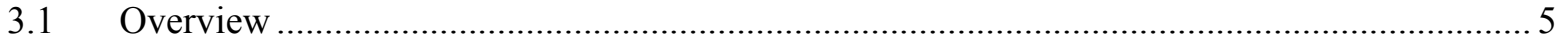

3.2 AOV Failure Probability and Failure Rate Trends ............................................................ 6

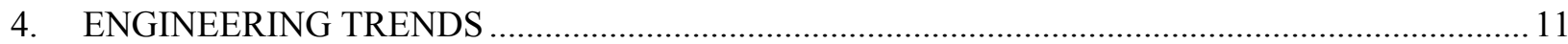

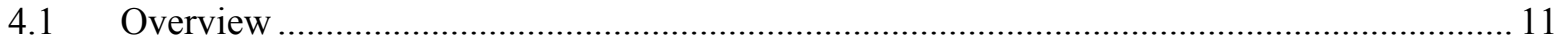

4.2 AOV Engineering Analysis by Failure Modes............................................................ 19

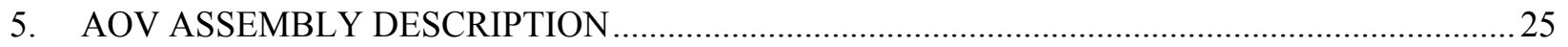

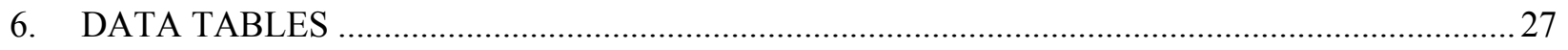

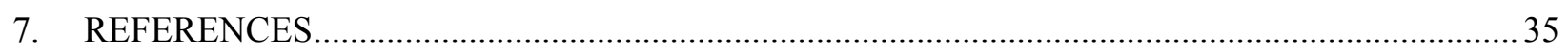

FIGURES

1. Failure probability estimate trend for AOV FTOC, all systems, industry-wide trend of AOVs

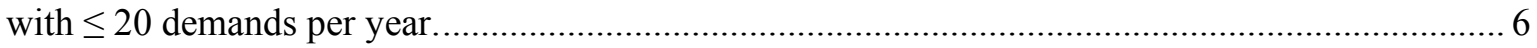

2. Failure probability estimate trend for AOV FTOC, all systems, industry-wide trend of AOVs

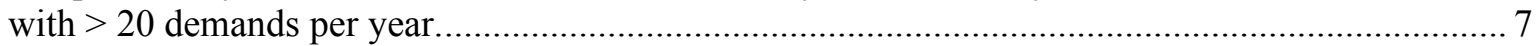

3. Failure rate estimate trend for AOV FTOP, all systems, industry-wide trend of AOVs with $\leq$ 20 demands per year.

4. Failure rate estimate trend for AOV FTOP, all systems, industry-wide trend of AOVs with > 20 demands per year.

5. Failure rate estimate trend for AOV SO, all systems, industry-wide trend of AOVs with $\leq 20$ demands per year.

6. Failure rate estimate trend for AOV SO, all systems, industry-wide trend of AOVs with $>20$ demands per year.

7. Frequency (demands per reactor year) of AOV operation demands, $\leq 20$ demands per year. 
8. Frequency (demands per reactor year) of AOV operation demands, $>20$ demands per year.

9. Frequency (failures per reactor year) of AOV FTOC events $\leq 20$ demands per year. ....................... 13

10. Frequency (failures per reactor year) of AOV FTOC events $>20$ demands per year. ...................... 13

11. Frequency (failures per reactor year) of AOV FTOP events $\leq 20$ demands per year....................... 14

12. Frequency (failures per reactor year) of AOV FTOP events $>20$ demands per year........................ 14

13. Frequency (failures per reactor year) of AOV SO events $\leq 20$ demands per year............................ 15

14. Frequency (failures per reactor year) of AOV SO events $>20$ demands per year............................ 15

15. AOV failure breakdown by period, sub component, and failure mode .......................................... 21

16. AOV breakdown by time period, cause group, and failure mode .................................................. 22

17. AOV component failure distribution by period, failure mode, and method of detection. ................... 23

18. AOV component failure distribution by period, failure mode, and recovery................................. 24

\section{TABLES}

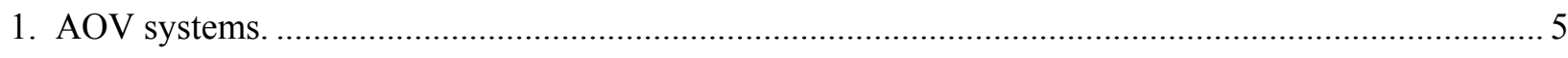

2. Industry-wide distributions of $\mathrm{p}$ (failure probability) and $\lambda$ (hourly rate) for AOVs $(\leq 20$

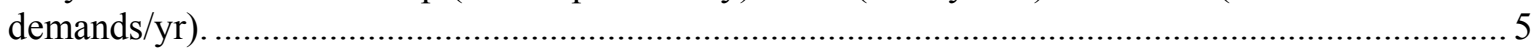

3. Summary of AOV failure counts for the FTOC failure mode over time by system $\leq 20$

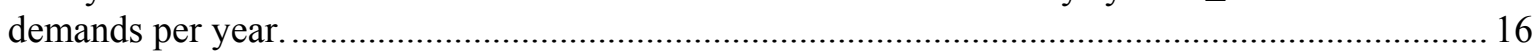

4. Summary of AOV failure counts for the FTOP failure mode over time by system $\leq 20$

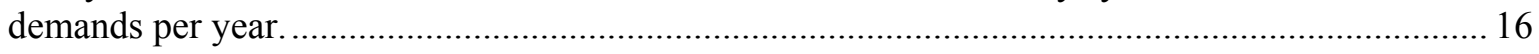

5. Summary of AOV failure counts for the SO failure mode over time by system $\leq 20$ demands

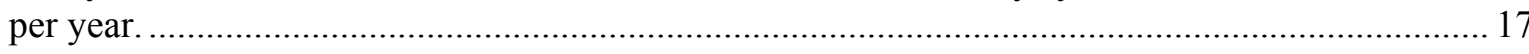

6. Summary of AOV failure counts for the FTOC failure mode over time by system $>20$ demands per year.

7. Summary of AOV failure counts for the FTOP failure mode over time by system $>20$ demands per year.

8. Summary of AOV failure counts for the SO failure mode over time by system $>20$ demands

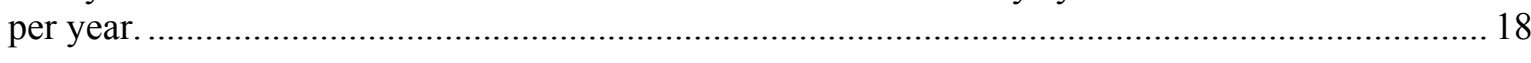

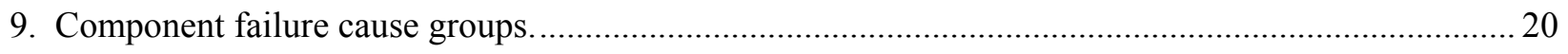

10. Plot data for industry-wide AOV FTOC trend with $\leq 20$ demands per year. Figure 1 ................... 27 
11. Plot data for industry-wide AOV FTOC trend with $>20$ demands per year. Figure 2 2....................28

12. Plot data for industry-wide AOV FTOP trend with $\leq 20$ demands per year. Figure 3 .................... 28

13. Plot data for industry-wide AOV FTOP trend with $>20$ demands per year. Figure 4 .................... 29

14. Plot data for industry-wide AOV SO trend with $\leq 20$ demands per year. Figure 5 ........................29

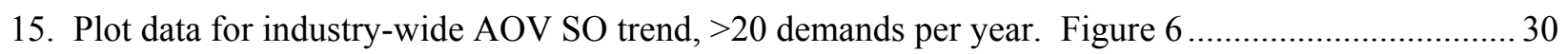

16. Plot data for frequency (events per reactor year) of AOV operation demands with $\leq 20$

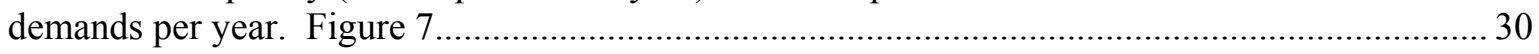

17. Plot data for frequency (events per reactor year) of AOV operation demands with $>20$

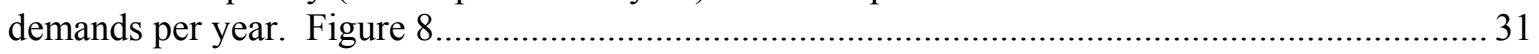

18. Plot data for frequency (events per reactor year) of AOV FTOC events with $\leq 20$ demands

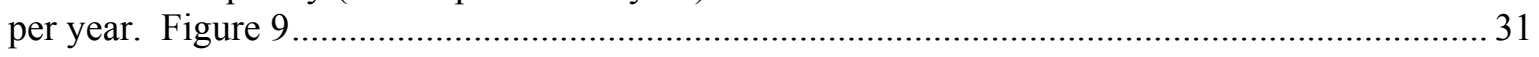

19. Plot data for frequency (events per reactor year) of AOV FTOC events with $>20$ demands

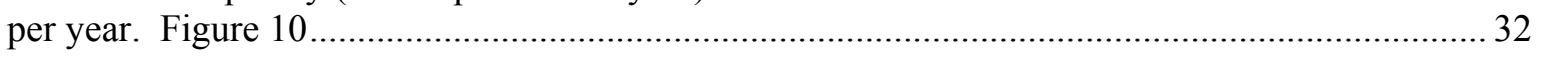

20. Plot data for frequency (events per reactor year) of AOV FTOP events with $\leq 20$ demands

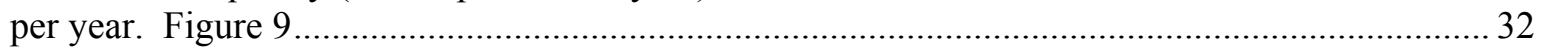

21. Plot data for frequency (events per reactor year) of AOV FTOP events with $>20$ demands

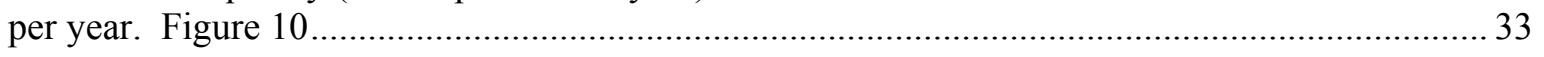

22. Plot data for frequency (events per reactor year) of AOV SO events $\leq 20$ demands per year.

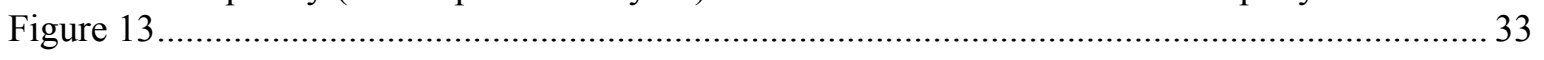

23. Plot data for frequency (events per reactor year) of AOV SO events $>20$ demands per year. Figure 14 


\section{ACRONYMS}

$\begin{array}{ll}\text { AOV } & \text { air-operated valve } \\ \text { EPIX } & \text { Equipment Performance and Information Exchange } \\ \text { FTOC } & \begin{array}{l}\text { failure-to-open/close } \\ \text { failure to operate or control } \\ \text { FTOP } \\ \text { FY }\end{array} \\ \text { fiscal year }\end{array}$




\section{Enhanced Component Performance Study: Air-Operated Valves 1998-2012}

\section{INTRODUCTION}

This report presents an enhanced performance evaluation of air-operated valves (AOVs) at U.S. commercial nuclear power plants. This report does not estimate values for use in probabilistic risk assessments, but does evaluate component performance over time. The 2010 Component Reliability Update (Reference 1), which is an update to Reference 2 (NUREG/CR-6928), reports the current AOV unreliability estimates using Equipment Performance and Information Exchange (EPIX) data from 1998 through 2010 for use in probabilistic risk assessments.

The data used in this study are based on the operating experience failure reports from fiscal year (FY)-98 through FY-12 for the component reliability as reported in EPIX. The AOV failure modes considered are failure-to-open/close (FTOC), (failure to operate or control) (FTOP), and spurious operation (SO). The component reliability estimates and the reliability data are trended for the most recent 10-year period while yearly estimates for reliability are provided for the entire active period.

Previously, the study relied on operating experience obtained from licensee event reports, Nuclear Plant Reliability Data System (NPRDS), and EPIX. The EPIX database, which includes as a subset the Mitigating Systems Performance Index (MSPI) designated devices, has matured to the point where component availability and reliability can be estimated with a higher degree of assurance of accuracy. In addition, the population of data is much larger than the population used in the previous study.

The objective of the effort for the updated component performance studies is to obtain annual performance trends of failure rates and probabilities. An overview of the trending methods, glossary of terms, and abbreviations can be found in the Overview and Reference document on the Reactor Operational Experience Results and Databases web page.

The objective of the enhanced component performance study is to present an analysis of factors that could influence the system and component trends in addition to annual performance trends of failure rates and probabilities. Engineering analyses were performed with respect to time period and failure mode (Section 4.2). The factors analyzed are: sub-component, failure cause, detection method, recovery. 


\section{SUMMARY OF FINDINGS}

The results of this study are summarized in this section. Of particular interest is the existence of any statistically significant ${ }^{\mathrm{a}}$ increasing trends. In this update, no statistically significant increasing trends were identified in the AOV results.

Statistically significant decreasing trends were identified in the AOV results for the following:

- Frequency (demands per reactor year) of AOV operation demands, $\leq 20$ demands per year. (see Figure 7)

- Frequency (demands per reactor year) of AOV operation demands, $>20$ demands per year. (see Figure 8)

Considering the low-demand AOVs; Table 3 shows that $94 \%$ of the AOV FTOC failures occurred in seven systems. Table 4 shows that $100 \%$ of the AOV FTOP failures occurred in seven systems. Similarly, Table 5 shows that $91 \%$ of the AOV SO failures occurred in four systems.

Considering the high-demand AOVs; Table 6 shows that $94 \%$ of the AOV FTOC failures occurred in five systems. Table 7 shows that $93 \%$ of the AOV FTOP failures occurred in three systems. Similarly, Table 8 shows that $100 \%$ of the AOV SO failures occurred in five systems.

a. Statistical significance is defined in terms of the ' $p$-value.' A p-value is a probability indicating whether to accept or reject the null hypothesis that there is no trend in the data. P-values of less than or equal to 0.05 indicate that we are $95 \%$ confident that there is a trend in the data (reject the null hypothesis of no trend.) By convention, we use the "Michelin Guide" scale: p-value $<0.05$ (statistically significant), p-value $<0.01$ (highly statistically significant); p-value $<0.001$ (extremely statistically significant). 


\section{FAILURE PROBABILITIES AND FAILURE RATES}

\subsection{Overview}

Trends of industry-wide failure probabilities and failure rates of AOVs have been calculated from the operating experience for the FTOC, FTOP, and SO failure modes. The AOV data set obtained from EPIX was segregated to AOVs with $\leq 20$ demands/yr and AOVs with $>20$ demands/yr and includes AOVs in the systems listed in Table 1. Reference 1 lists the industry failure data for AOVs with $\leq 20$ demands/yr.

Table 2 shows industry-wide failure probability and failure rate results for the AOV with $\leq 20$ demands/yr from Reference 1. No results are shown for $>20$ demands/yr AOVs because Reference 1 does not present results for $>20$ demands/yr.

The AOVs are assumed to operate both when the reactor is critical and during shutdown periods. The number of valves in operation is assumed to be constant throughout the study period. All demand types are considered - testing, non-testing, and, as applicable, engineered safety feature demands.

Table 1. AOV systems.

\begin{tabular}{llrcr} 
& & \multicolumn{3}{c}{ AOV Component Count } \\
\cline { 3 - 5 } System & \multicolumn{1}{c}{ Description } & Total & $\mathbf{5 2 0}$ demands/yr & $\mathbf{> 2 0}$ demands/yr \\
AFW & Auxiliary feedwater & 360 & 193 & 167 \\
CCW & Component cooling water & 436 & 295 & 141 \\
CRD & Control rod drive & 117 & 66 & 51 \\
CSR & Containment spray recirculation & 30 & 28 & 2 \\
HCl & High pressure coolant injection & 14 & 7 & 7 \\
HPI & High pressure injection & 94 & 70 & 24 \\
ISO & Isolation condenser & 10 & 6 & 4 \\
LCS & Low pressure core spray & 12 & 10 & 2 \\
RCI & Reactor core isolation & 8 & 6 & 2 \\
RCS & Reactor coolant & 109 & 52 & 57 \\
RHR & Residual heat removal & 259 & 126 & 133 \\
SWN & Normally running service water & 511 & 296 & 215 \\
& Total & $\mathbf{1 9 6 0}$ & $\mathbf{1 1 5 5}$ & $\mathbf{8 0 5}$ \\
\hline
\end{tabular}

Table 2. Industry-wide distributions of $\mathrm{p}$ (failure probability) and $\lambda$ (hourly rate) for AOVs $(\leq 20$ demands/yr).

\begin{tabular}{lcccccccc}
\hline \multirow{2}{*}{$\begin{array}{c}\text { Failure } \\
\text { Mode }\end{array}$} & $\mathbf{5 \%}$ & & Median & Mean & $\mathbf{9 5 \%}$ & \multicolumn{3}{c}{ Distribution } \\
\cline { 6 - 8 } & FTOC & $6.27 \mathrm{E}-05$ & $6.86 \mathrm{E}-04$ & $9.51 \mathrm{E}-04$ & $2.74 \mathrm{E}-03$ & Beta & $\alpha$ & $\beta$ \\
\hline FTOP & $2.66 \mathrm{E}-08$ & $1.93 \mathrm{E}-07$ & $2.49 \mathrm{E}-07$ & $6.59 \mathrm{E}-07$ & Gamma & 1.11 & $1.168 \mathrm{E}+03$ \\
\hline SO & $2.04 \mathrm{E}-09$ & $7.46 \mathrm{E}-08$ & $1.31 \mathrm{E}-07$ & $4.49 \mathrm{E}-07$ & Gamma & 0.68 & $5.719 \mathrm{E}+06$ \\
\hline
\end{tabular}




\subsection{AOV Failure Probability and Failure Rate Trends}

Trends in failure probabilities and failure rates are shown in Figures 1-6. The data for the trend plots are contained in Tables $10-15$, respectively.

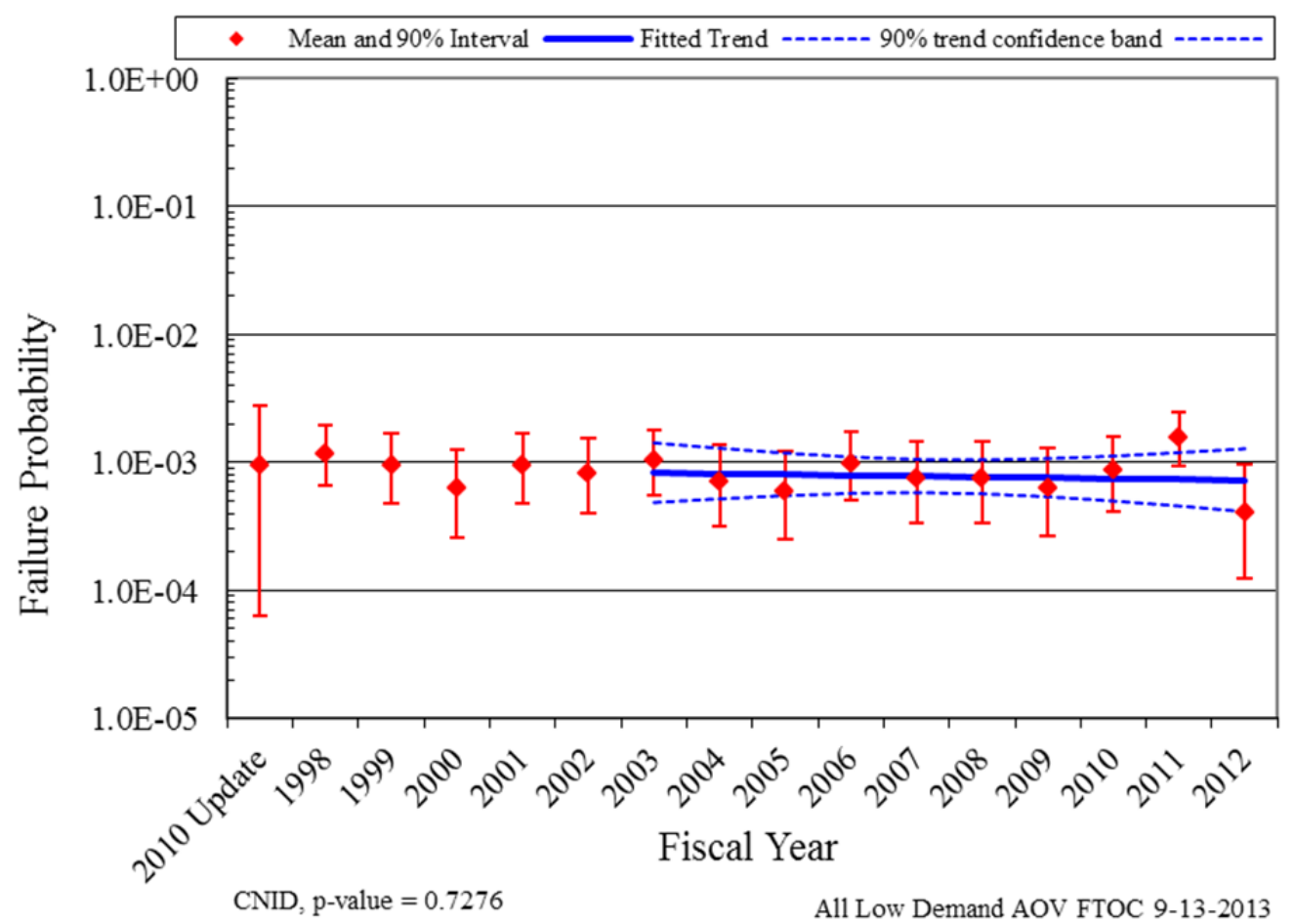

Figure 1. Failure probability estimate trend for AOV FTOC, all systems, industry-wide trend of AOVs with $\leq 20$ demands per year. 


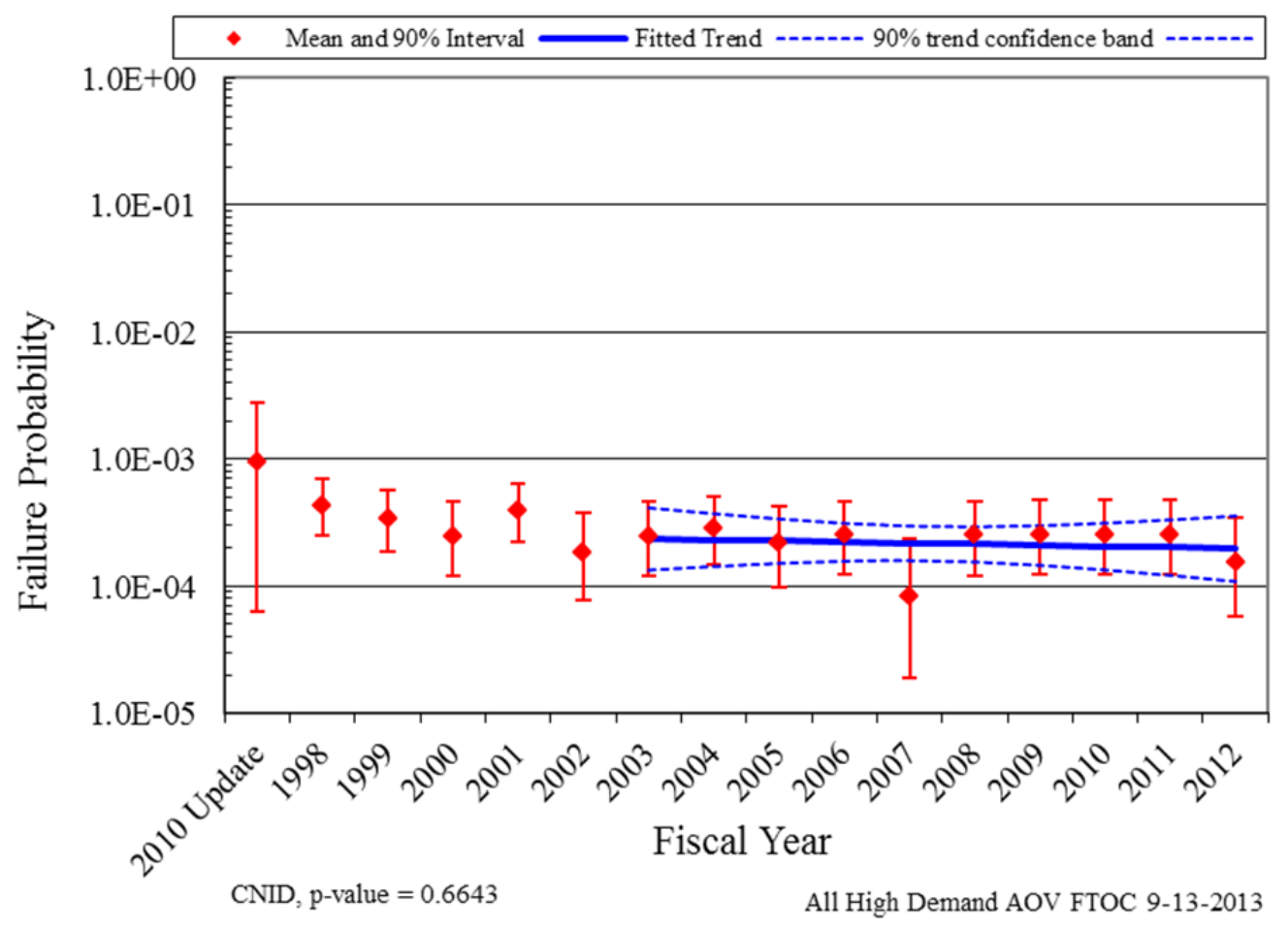

Figure 2. Failure probability estimate trend for AOV FTOC, all systems, industry-wide trend of AOVs with $>20$ demands per year.

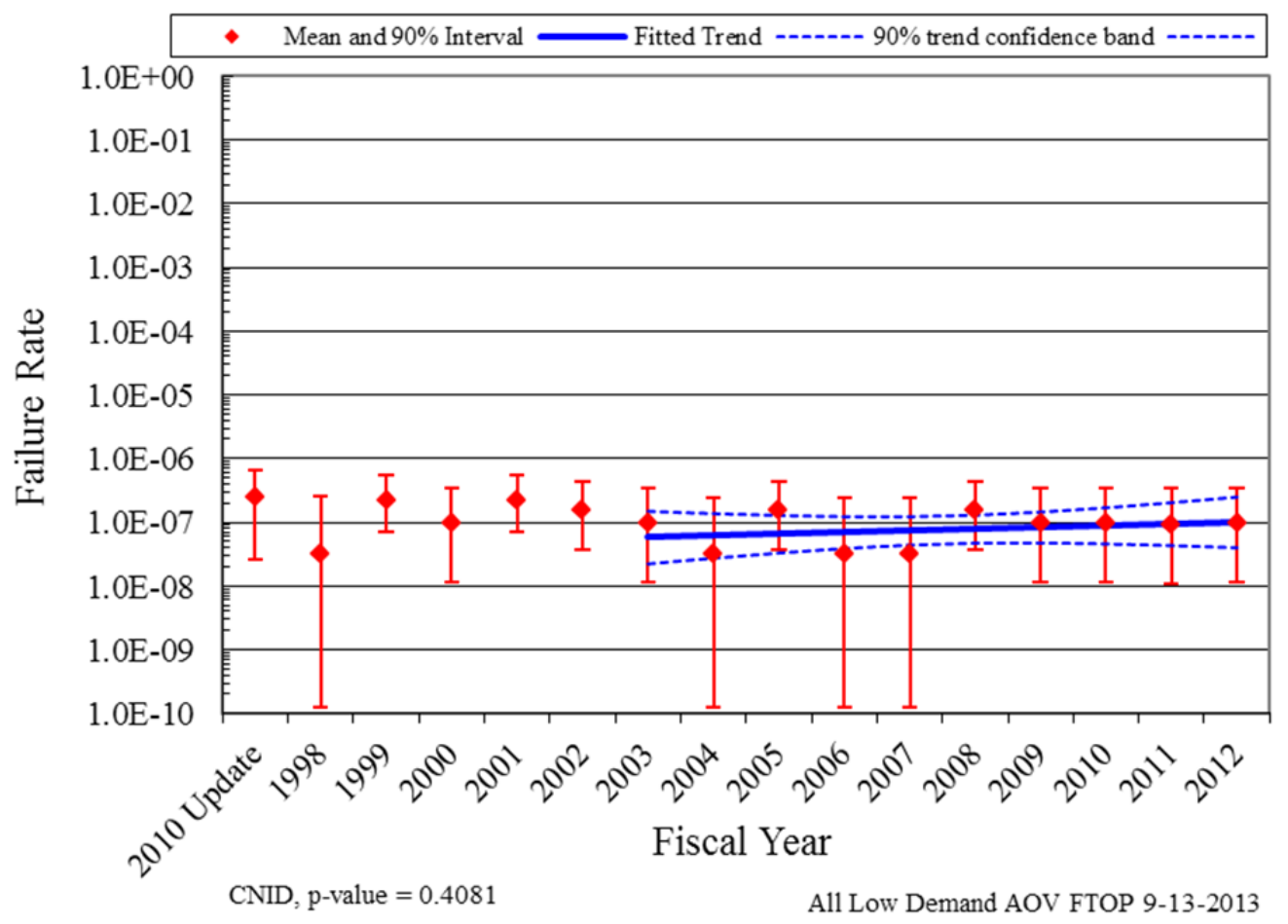

Figure 3. Failure rate estimate trend for AOV FTOP, all systems, industry-wide trend of AOVs with $\leq 20$ demands per year. 


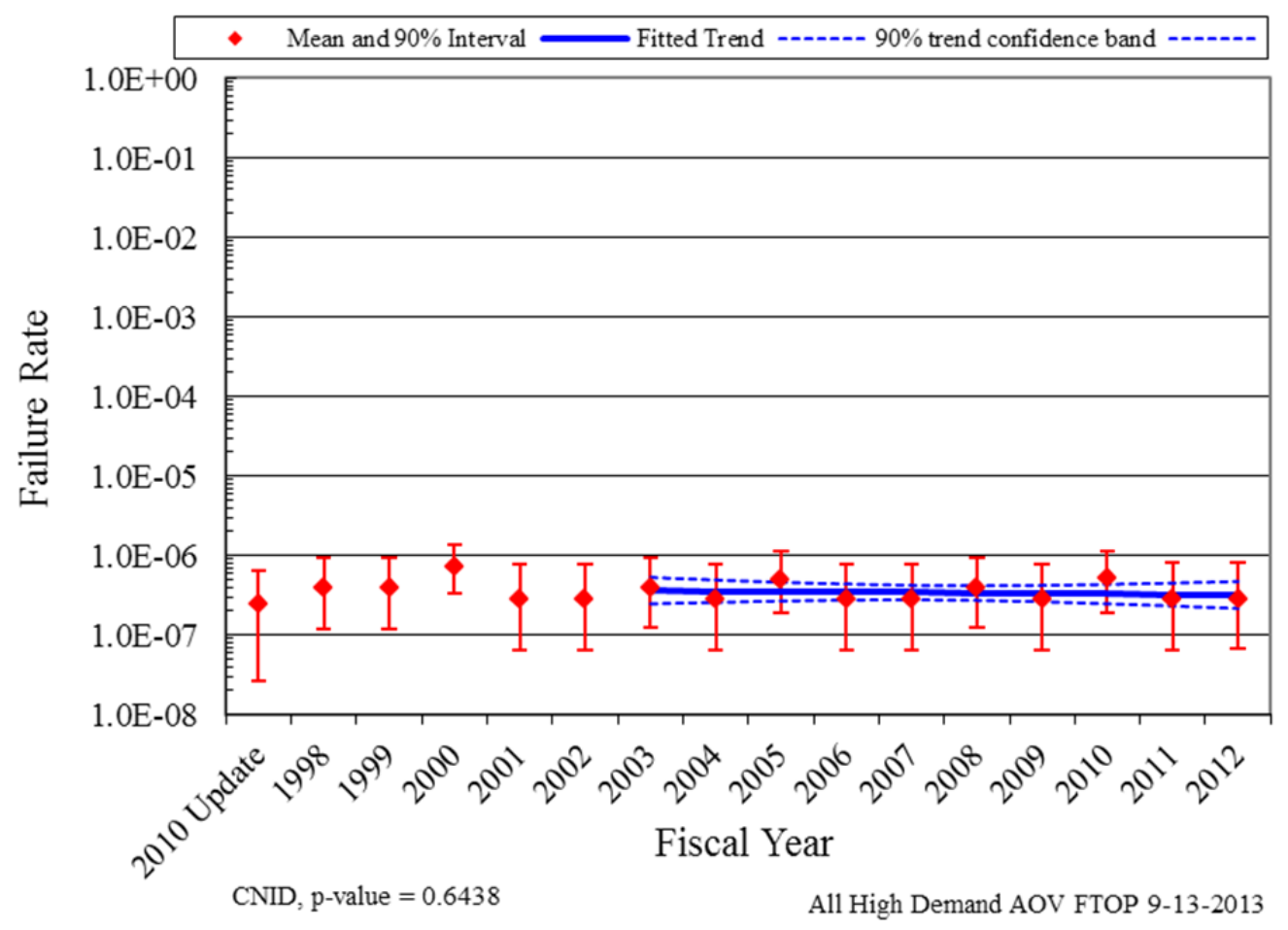

Figure 4. Failure rate estimate trend for AOV FTOP, all systems, industry-wide trend of AOVs with $>20$ demands per year.

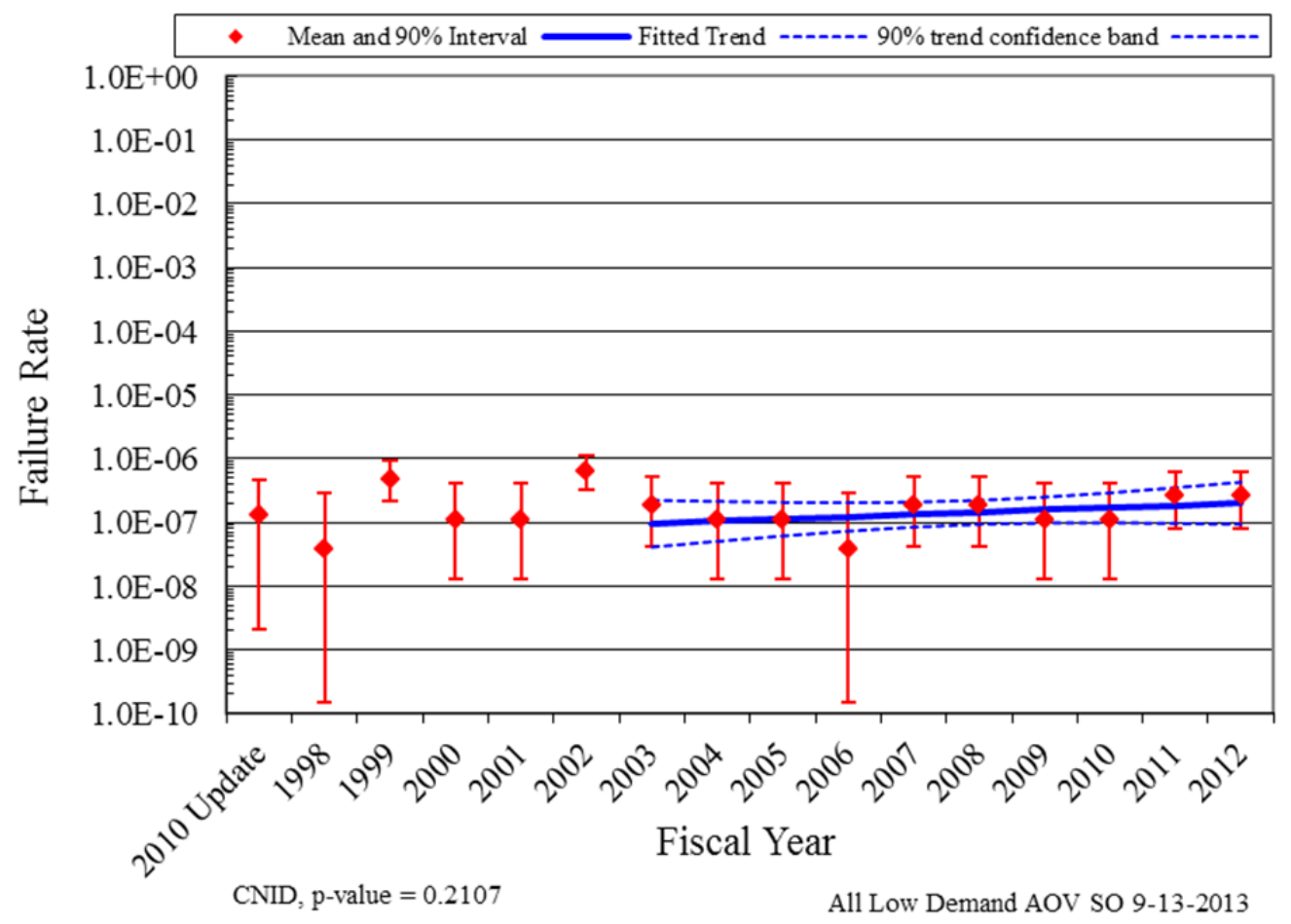

Figure 5. Failure rate estimate trend for AOV SO, all systems, industry-wide trend of AOVs with $\leq 20$ demands per year. 


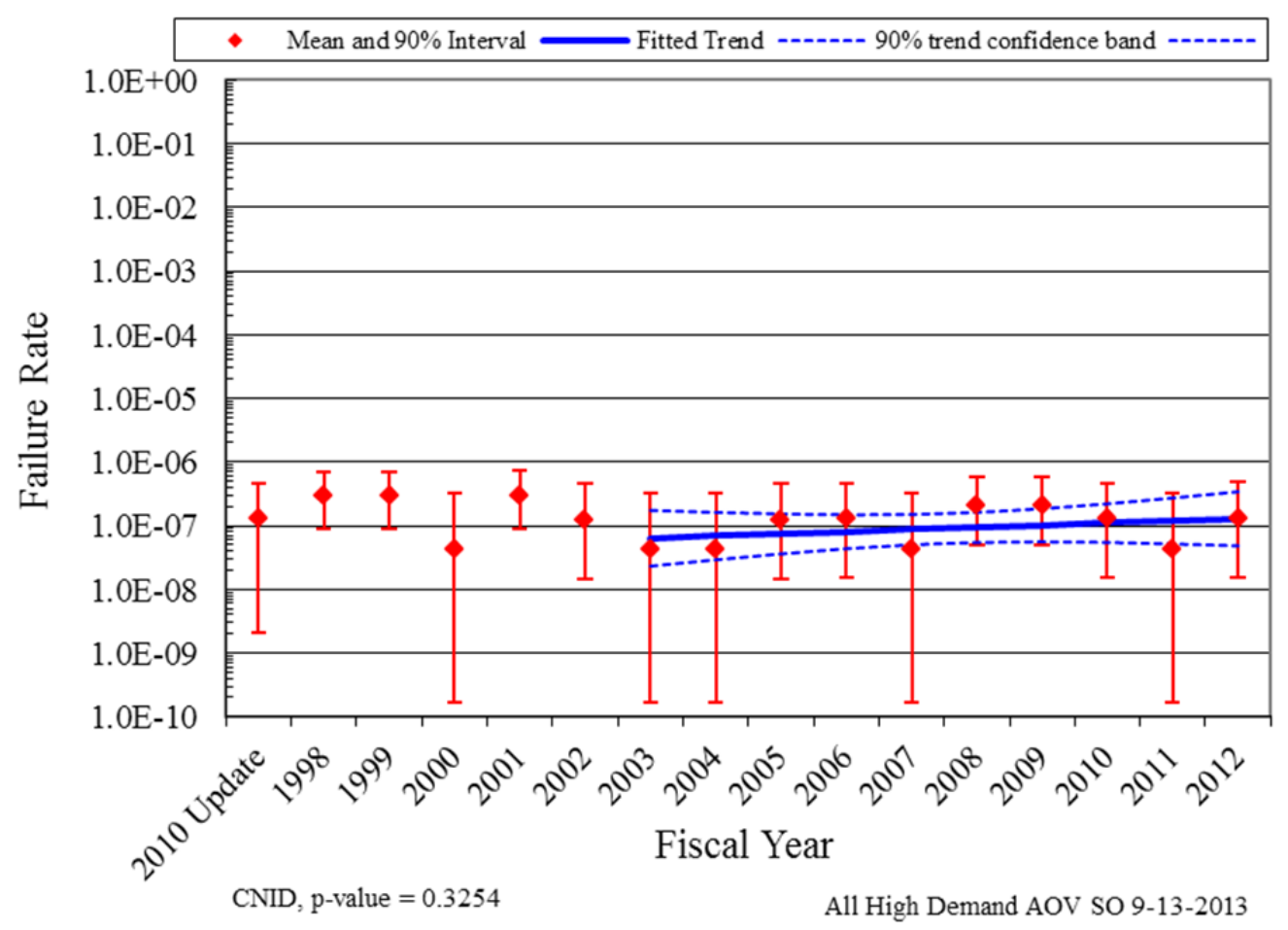

Figure 6. Failure rate estimate trend for AOV SO, all systems, industry-wide trend of AOVs with $>20$ demands per year.

In the plots, the means of the posterior distributions from the Bayesian update process were trended across the years. The posterior distributions were also used for the vertical bounds for each year. The 5th and 95th percentiles of these distributions give an indication of the relative variation from year to year in the data. When there are no failures, the interval is larger than the interval for years when there are one or more failures. The larger interval reflects the uncertainty that comes from having little information in that year's data. Such uncertainty intervals are determined by the prior distribution. In each plot, a relatively "flat" constrained noninformative prior distribution is used, which has large bounds.

The horizontal curves plotted around the regression lines in the graphs form 90 percent simultaneous confidence bands for the fitted lines. The bounds are larger than ordinary confidence intervals for the trended values because they form a band that has a $90 \%$ probability of containing the entire line. In the lower left hand corner of the trend figures, the regression p-values are reported. They come from a statistical test on whether the slope of the regression line might be zero. Low p-values indicate that the slopes are not likely to be zero, and that trends exist. Further information on the trending methods is provided in Section 2 of the Overview and Reference document. A final feature of the trend graphs is that the baseline industry values from

Table 2 are shown for comparison. 


\section{ENGINEERING TRENDS}

\subsection{Overview}

This section presents frequency trends for AOV failures and demands. The data are normalized by reactor year for plants that have the equipment being trended. Figure 7 shows the trend for total AOV demands of $\leq 20$ demands per reactor-year AOVs. Figure 9 shows the trend in failure events for FTOC mode for AOV $\leq 20$ demands, and Figure 13 shows the trend for the $\mathrm{SO}$ failure events for AOV $\leq 20$ demands.

Figure 8 shows the trend for total AOV $>20$ demands per reactor-year of $>20$ demands per reactoryear AOVs. Figure 10 shows the trend in failure events for FTOC mode for AOV $>20$ demands, and Figure 14 shows the trend for the $\mathrm{SO}$ failure events for $\mathrm{AOV}>20$ demands.

Table 3 summarizes the failures by system, year, and the FTOC failure mode for AOV $\leq 20$ demands. The systems contributing $50 \%$ or more (in bold) to the FTOC failure mode are AFW, CCW, HPI, RHR, SWN, and SWS. Table 4 summarizes the failures by system, year, and the FTOP failure mode for AOV $\leq 20$ demands. The systems contributing $50 \%$ or more (in bold) to the FTOP failure mode are AFW, $\mathrm{CCW}, \mathrm{SWN}$, and SWS. Table 5 summarizes the failures by system, year, and the SO failure mode for AOV $\leq 20$ demands. The systems together contributing $50 \%$ or more (in bold) to the SO failure mode are $\mathrm{AFW}, \mathrm{CCW}$, and CRD.

Table 6 summarizes the failures by system, year, and the FTOC failure mode for AOV $>20$ demands. The systems contributing 50\% or more (in bold) to the FTOC failure mode are AFW, RHR, and SWN. Table 7 summarizes the failures by system, year, and the FTOP failure mode for AOV $>20$ demands. The systems contributing 50\% or more (in bold) to the FTOP failure mode are AFW and SWN. Table 8 summarizes the failures by system, year, and the SO failure mode for AOV $>20$ demands. The systems contributing $50 \%$ or more (in bold) to the SO failure mode are AFW, RHR, and SWN.

Tables 16-23 provide the plot data for frequency (per reactor year) of AOV demands, FTOC events, FTOP events, and SO events, respectively. The systems from Table 2 are trended together for each figure. The rate methods described in Section 2 of the Overview and Reference document are used. 


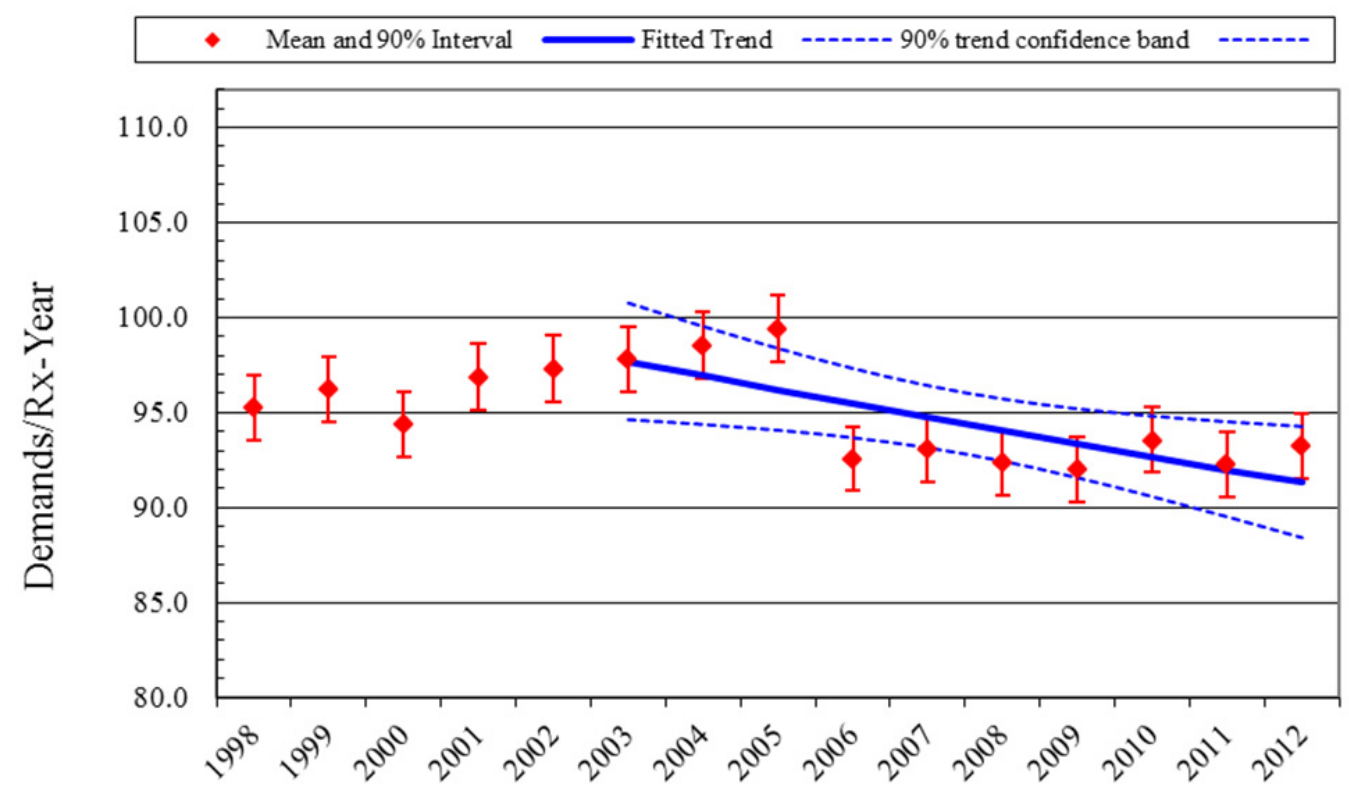

Fiscal Year

CNID, p-value $=0.0138$

All Low Demand AOV FTOC 10-22-2013

Figure 7. Frequency (demands per reactor year) of AOV operation demands, $\leq 20$ demands per year.

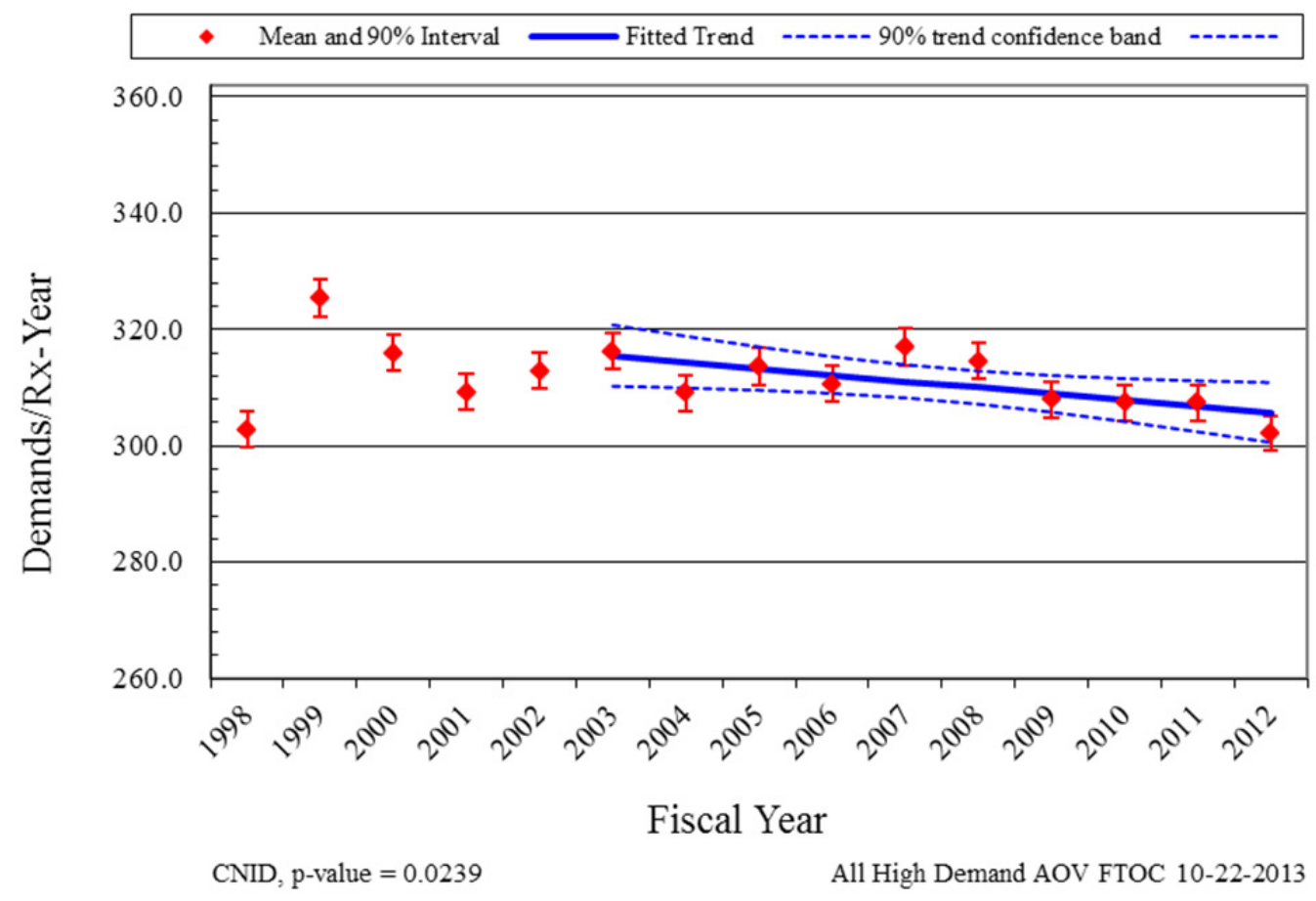

Figure 8. Frequency (demands per reactor year) of AOV operation demands, $>20$ demands per year. 


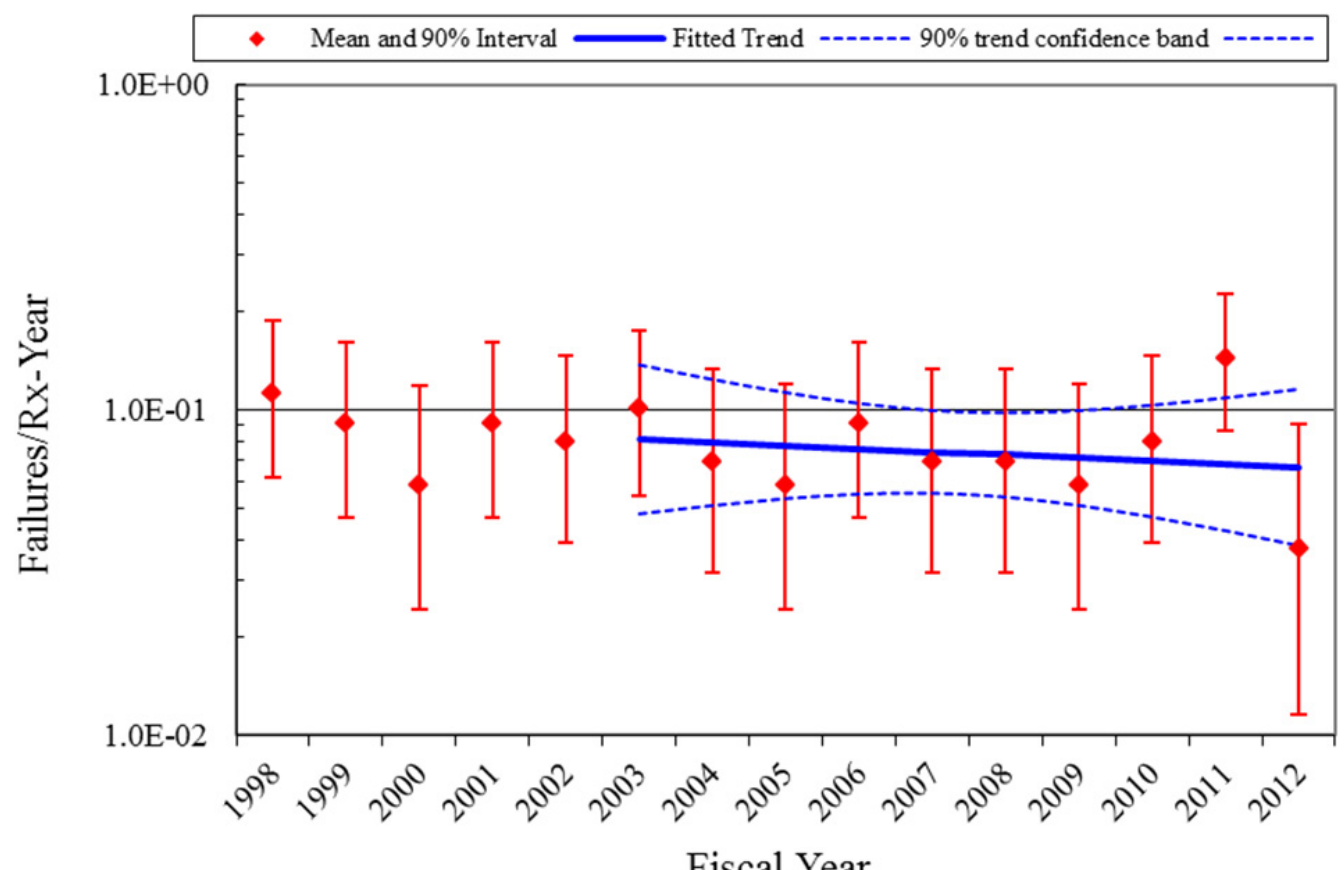

Fiscal Year

CNID, p-value $=0.6020$

All Low Demand AOV FTOC 9-11-2013

Figure 9. Frequency (failures per reactor year) of AOV FTOC events $\leq 20$ demands per year.

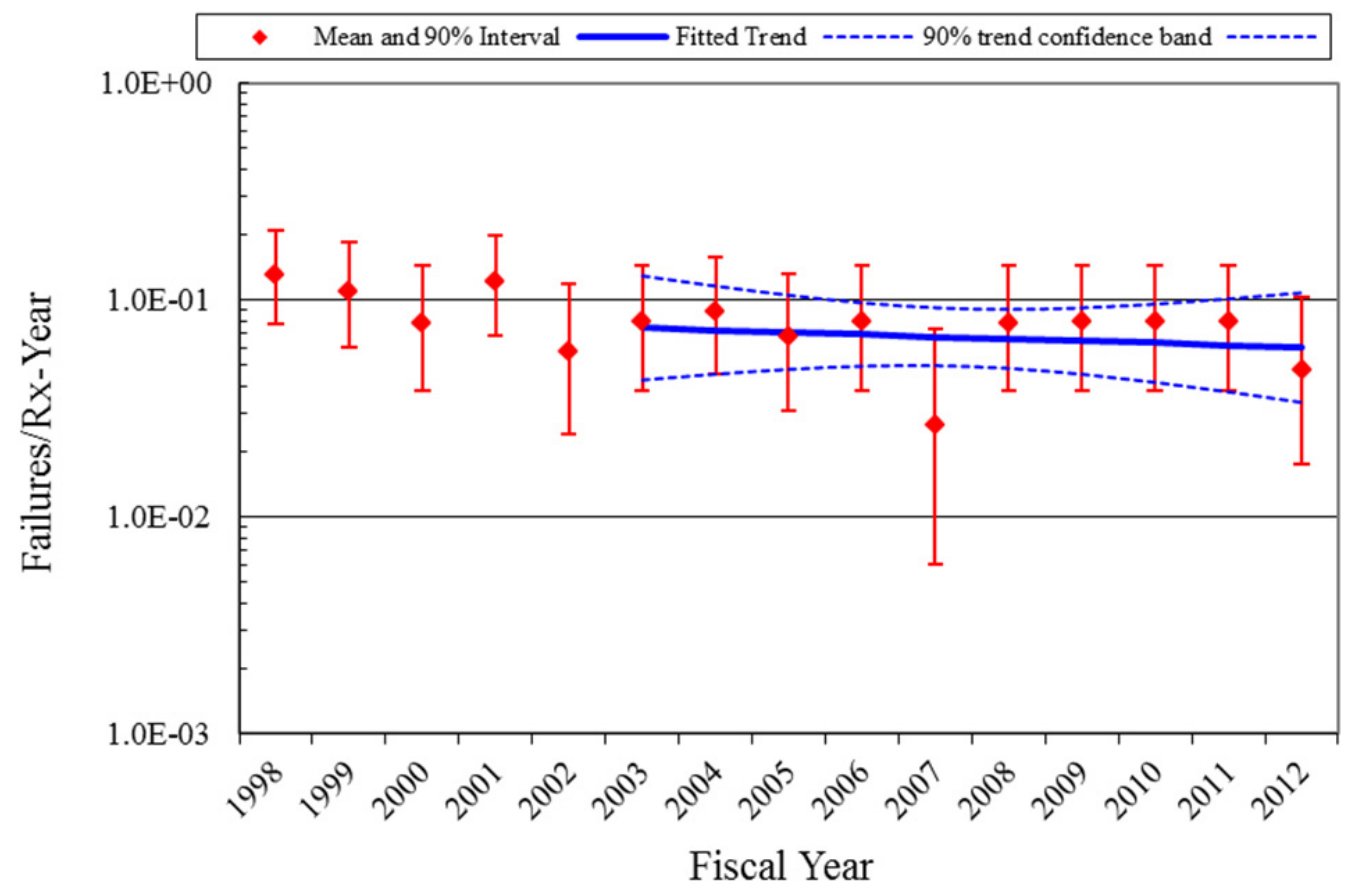

CNID, p-value $=0.6016$

All High Demand AOV FTOC 9-11-2013

Figure 10. Frequency (failures per reactor year) of AOV FTOC events $>20$ demands per year. 


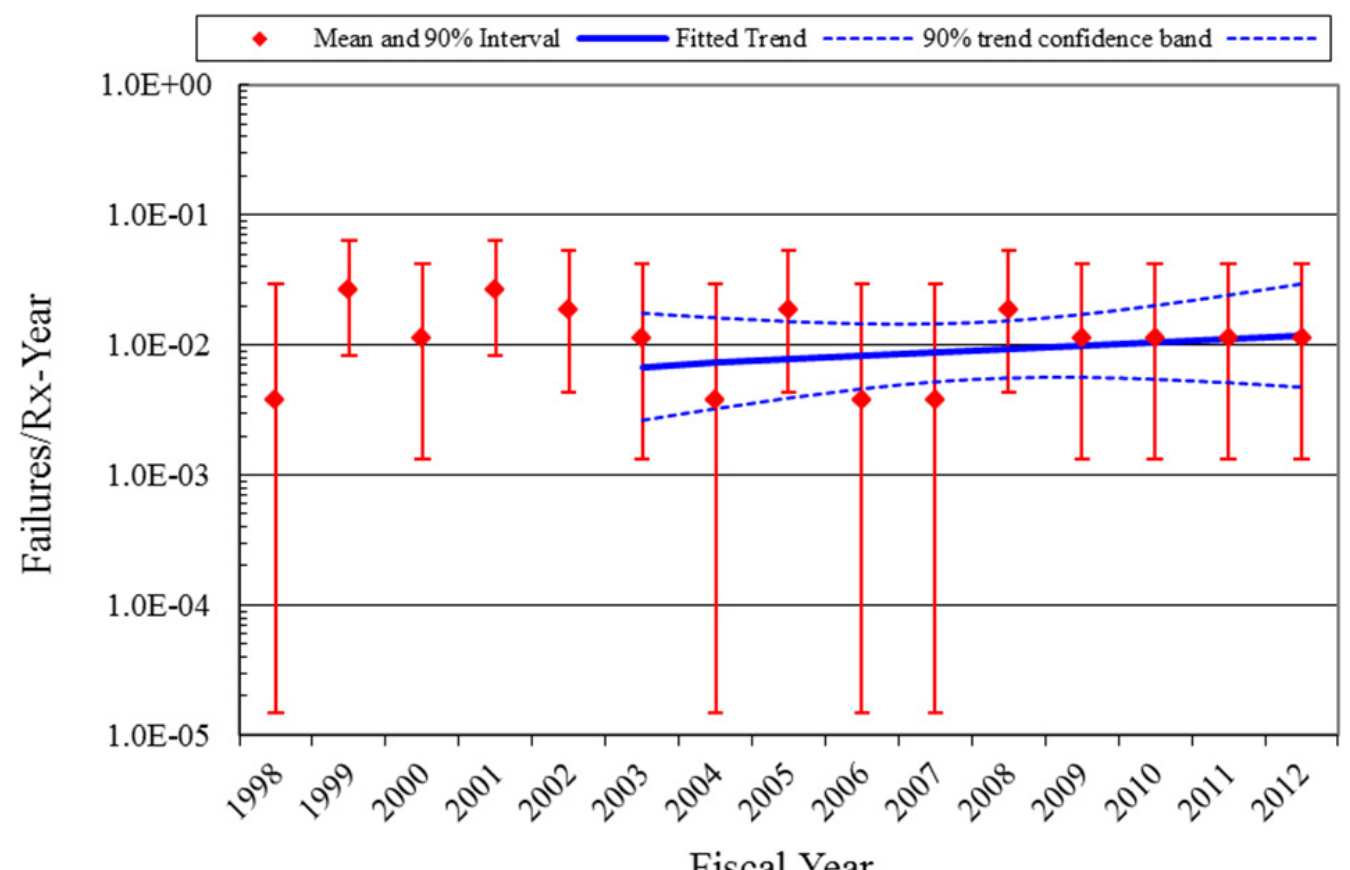

CNID, p-value $=0.4047$

All Low Demand AOV FTOP 9-11-2013

Figure 11. Frequency (failures per reactor year) of AOV FTOP events $\leq 20$ demands per year.

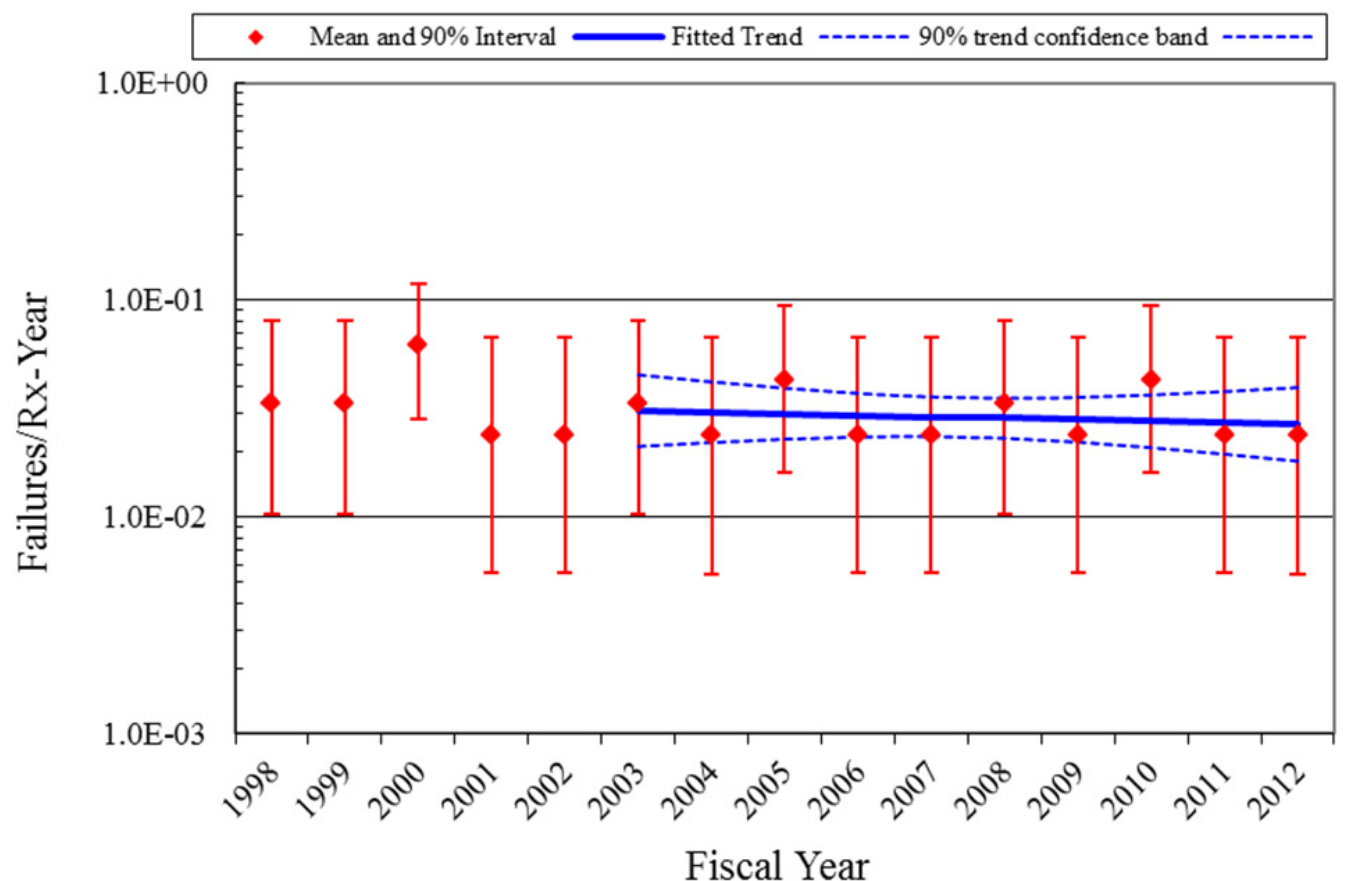

CNID, p-value $=0.5910$

All High Demand AOV FTOP 9-11-2013

Figure 12. Frequency (failures per reactor year) of AOV FTOP events $>20$ demands per year. 


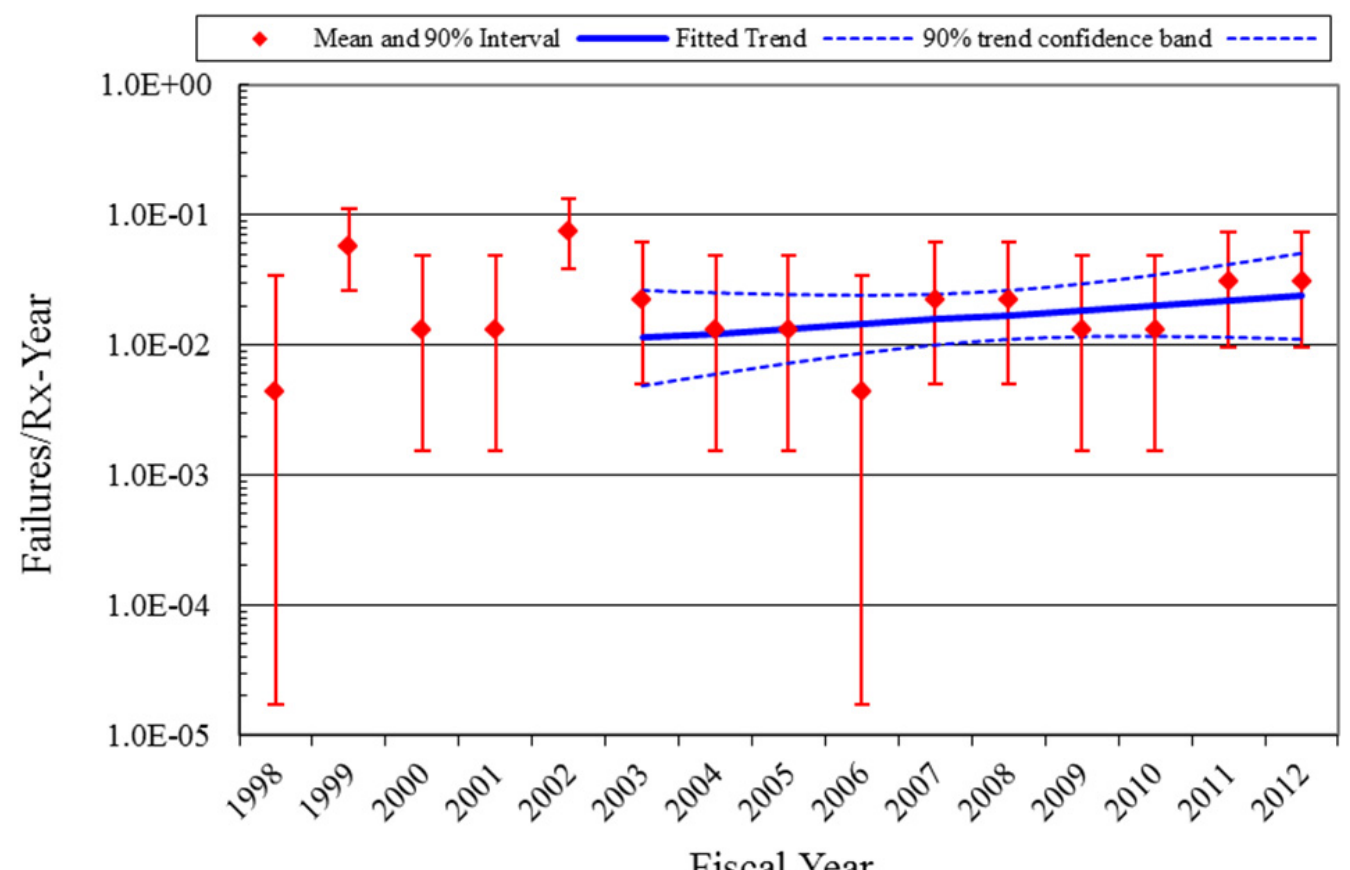

CNID, p-value $=0.2089$

All Low Demand AOV SO 9-11-2013

Figure 13. Frequency (failures per reactor year) of AOV SO events $\leq 20$ demands per year.

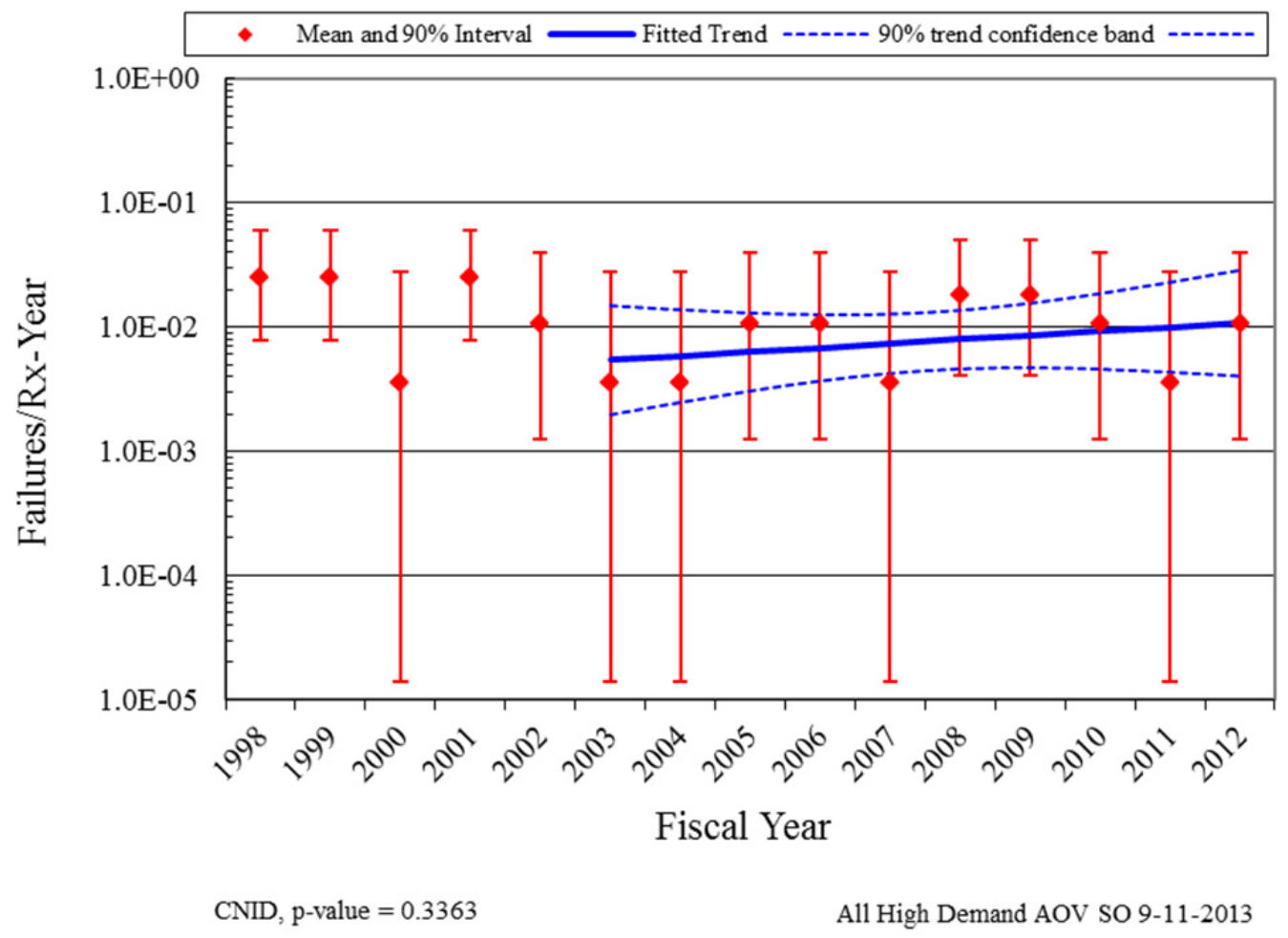

Figure 14. Frequency (failures per reactor year) of AOV SO events $>20$ demands per year. 
Table 3. Summary of AOV failure counts for the FTOC failure mode over time by system $\leq 20$ demands per year.

\begin{tabular}{|c|c|c|c|c|c|c|c|c|c|c|c|c|c|c|c|c|c|c|c|}
\hline $\begin{array}{c}\text { System } \\
\text { Code }\end{array}$ & $\begin{array}{l}\text { Valve } \\
\text { Count }\end{array}$ & $\begin{array}{l}\text { Valve } \\
\text { Percent }\end{array}$ & FY-98 & FY-99 & FY-00 & FY-01 & FY-02 & FY-03 & FY-04 & FY-05 & FY-06 & FY-07 & FY-08 & FY-09 & FY-10 & FY-11 & FY-12 & Total & $\begin{array}{c}\text { Percent } \\
\text { of } \\
\text { Failures }\end{array}$ \\
\hline AFW & 194 & $16.7 \%$ & 5 & 1 & 3 & 3 & 3 & & & 2 & 2 & 1 & 1 & 1 & 3 & & & 25 & $23.6 \%$ \\
\hline CCW & 295 & $25.4 \%$ & & & & 2 & 3 & & 1 & 1 & 2 & 2 & 1 & & 1 & 3 & & 16 & $15.1 \%$ \\
\hline CRD & 66 & $5.7 \%$ & & 1 & & & & & & & & & & & & & 1 & 2 & $1.9 \%$ \\
\hline CSR & 28 & $2.4 \%$ & & & & & & & & 1 & & 1 & & & & & & 2 & $1.9 \%$ \\
\hline HPI & 70 & $6.0 \%$ & & & & & & 2 & & & 1 & & 1 & & & 3 & & 7 & $6.6 \%$ \\
\hline LCS & 10 & $0.9 \%$ & & 1 & & & & & & & & & & & & & & 1 & $0.9 \%$ \\
\hline $\mathrm{RCl}$ & 6 & $0.5 \%$ & & & & & & & & & & & 1 & & & & & 1 & $0.9 \%$ \\
\hline RCS & 52 & $4.5 \%$ & & 1 & & & & 1 & 1 & & & & & 1 & 1 & 1 & & 6 & $5.7 \%$ \\
\hline RHR & 126 & $10.8 \%$ & 1 & 1 & & & 1 & 1 & & & 2 & 1 & & 1 & 1 & & & 9 & $8.5 \%$ \\
\hline SWN & 296 & $25.5 \%$ & 4 & 3 & 2 & 3 & & 1 & 4 & 1 & 1 & 1 & 2 & 2 & 1 & 4 & 1 & 30 & $28.3 \%$ \\
\hline SWS & 20 & $1.7 \%$ & & & & & & 4 & & & & & & & & 2 & 1 & 7 & $6.6 \%$ \\
\hline Total & 1163 & $100 \%$ & 10 & 8 & 5 & 8 & 7 & 9 & 6 & 5 & 8 & 6 & 6 & 5 & 7 & 13 & 3 & 106 & $100 \%$ \\
\hline
\end{tabular}

Table 4. Summary of AOV failure counts for the FTOP failure mode over time by system $\leq 20$ demands per year.

\begin{tabular}{|c|c|c|c|c|c|c|c|c|c|c|c|c|c|c|c|c|c|c|c|}
\hline $\begin{array}{c}\text { System } \\
\text { Code }\end{array}$ & $\begin{array}{l}\text { Valve } \\
\text { Count }\end{array}$ & $\begin{array}{c}\text { Valve } \\
\text { Percent }\end{array}$ & FY-98 & FY-99 & FY -00 & FY-01 & FY-02 & FY-03 & FY-04 & FY-05 & FY-06 & FY-07 & FY-08 & FY-09 & FY-10 & FY-11 & FY-12 & Total & $\begin{array}{c}\text { Percent } \\
\text { of } \\
\text { Failures }\end{array}$ \\
\hline AFW & 194 & $21.9 \%$ & & & 1 & & & & & & & & & & 1 & & & 2 & $11.1 \%$ \\
\hline CCW & 295 & $33.3 \%$ & & 1 & & 1 & 1 & & & 1 & & & 1 & 1 & & & & 6 & $33.3 \%$ \\
\hline HPI & 70 & $7.9 \%$ & & & & 1 & & & & & & & & & & & & 1 & $5.6 \%$ \\
\hline ISO & 6 & $0.7 \%$ & & & & & 1 & & & & & & & & & & & 1 & $5.6 \%$ \\
\hline $\mathrm{RCl}$ & 6 & $0.7 \%$ & & & & & & & & & & & & & & & 1 & 1 & $5.6 \%$ \\
\hline SWN & 296 & $33.4 \%$ & & 1 & & 1 & & 1 & & 1 & & & 1 & & & & & 5 & $27.8 \%$ \\
\hline SWS & 20 & $2.3 \%$ & & 1 & & & & & & & & & & & & 1 & & 2 & $11.1 \%$ \\
\hline Total & 887 & $100 \%$ & & 3 & 1 & 3 & 2 & 1 & & 2 & & & 2 & 1 & 1 & 1 & 1 & 18 & $100 \%$ \\
\hline
\end{tabular}


Table 5. Summary of AOV failure counts for the SO failure mode over time by system $\leq 20$ demands per year.

\begin{tabular}{|c|c|c|c|c|c|c|c|c|c|c|c|c|c|c|c|c|c|c|c|}
\hline $\begin{array}{c}\text { System } \\
\text { Code }\end{array}$ & $\begin{array}{l}\text { Valve } \\
\text { Count }\end{array}$ & $\begin{array}{c}\text { Valve } \\
\text { Percent }\end{array}$ & FY-98 & FY-99 & FY -00 & FY-01 & FY-02 & FY-03 & FY-04 & FY-05 & FY-06 & FY-07 & FY-08 & FY-09 & FY-10 & FY-11 & FY-12 & Total & $\begin{array}{c}\begin{array}{c}\text { Percent } \\
\text { of }\end{array} \\
\text { Failures }\end{array}$ \\
\hline AFW & 194 & $23.6 \%$ & & & & 1 & & 1 & 1 & 1 & & 1 & 1 & 1 & & 1 & & 8 & $25.0 \%$ \\
\hline $\mathrm{CCW}$ & 295 & $35.8 \%$ & & 1 & 1 & & 7 & & & & & 1 & & & 1 & 1 & 3 & 15 & $46.9 \%$ \\
\hline CRD & 66 & $8.0 \%$ & & 4 & & & & & & & & & & & & & & 4 & $12.5 \%$ \\
\hline HPI & 70 & $8.5 \%$ & & & & & & 1 & & & & & & & & & & 1 & $3.1 \%$ \\
\hline RCS & 52 & $6.3 \%$ & & 1 & & & 1 & & & & & & & & & & & 2 & $6.3 \%$ \\
\hline RHR & 126 & $15.3 \%$ & & & & & & & & & & & 1 & & & & & 1 & $3.1 \%$ \\
\hline SWS & 20 & $2.4 \%$ & & & & & & & & & & & & & & 1 & & 1 & $3.1 \%$ \\
\hline Total & 823 & 1 & & 6 & 1 & 1 & 8 & 2 & 1 & 1 & & 2 & 2 & 1 & 1 & 3 & 3 & 32 & $100 \%$ \\
\hline
\end{tabular}

Table 6. Summary of AOV failure counts for the FTOC failure mode over time by system $>20$ demands per year.

\begin{tabular}{|c|c|c|c|c|c|c|c|c|c|c|c|c|c|c|c|c|c|c|c|}
\hline $\begin{array}{c}\text { System } \\
\text { Code }\end{array}$ & $\begin{array}{l}\text { Valve } \\
\text { Count }\end{array}$ & $\begin{array}{c}\text { Valve } \\
\text { Percent }\end{array}$ & FY-98 & FY-99 & FY -00 & FY-01 & FY-02 & FY -03 & FY-04 & FY-05 & FY-06 & FY-07 & FY-08 & FY-09 & FY-10 & FY-11 & FY-12 & Total & $\begin{array}{c}\text { Percent } \\
\text { of } \\
\text { Failures }\end{array}$ \\
\hline AFW & 166 & $20.8 \%$ & & 1 & 1 & 3 & 1 & 2 & 5 & 3 & 3 & & 2 & & 1 & 2 & 3 & 27 & $25.2 \%$ \\
\hline CCW & 141 & $17.7 \%$ & 2 & & 3 & & & 1 & & & 1 & & & & 1 & & 1 & 9 & $8.4 \%$ \\
\hline CRD & 51 & $6.4 \%$ & 2 & & & & & & & & & & & & & & & 2 & $1.9 \%$ \\
\hline RCS & 57 & $7.1 \%$ & & & & 4 & & 2 & 2 & 1 & & 1 & & & 1 & & & 11 & $10.3 \%$ \\
\hline RHR & 133 & $16.7 \%$ & 1 & 7 & 1 & & 1 & 1 & & & 1 & 1 & 1 & 2 & 2 & 2 & & 20 & $18.7 \%$ \\
\hline SWN & 215 & $26.9 \%$ & 3 & 2 & 2 & 4 & 3 & 1 & 1 & 2 & 2 & & 4 & 5 & 2 & 3 & & 34 & $31.8 \%$ \\
\hline SWS & 35 & $4.4 \%$ & 4 & & & & & & & & & & & & & & & 4 & $3.7 \%$ \\
\hline Total & 798 & $100 \%$ & 12 & 10 & 7 & 11 & 5 & 7 & 8 & 6 & 7 & 2 & 7 & 7 & 7 & 7 & 4 & 107 & $100 \%$ \\
\hline
\end{tabular}


Table 7. Summary of AOV failure counts for the FTOP failure mode over time by system $>20$ demands per year.

\begin{tabular}{|c|c|c|c|c|c|c|c|c|c|c|c|c|c|c|c|c|c|c|c|}
\hline $\begin{array}{c}\text { System } \\
\text { Code }\end{array}$ & $\begin{array}{l}\text { Valve } \\
\text { Count }\end{array}$ & $\begin{array}{c}\text { Valve } \\
\text { Percent }\end{array}$ & FY-98 & FY-99 & FY -00 & FY-01 & FY-02 & FY-03 & FY-04 & FY-05 & FY-06 & FY-07 & FY-08 & FY-09 & FY-10 & FY-11 & FY-12 & Total & $\begin{array}{c}\text { Percent } \\
\text { of } \\
\text { Failures }\end{array}$ \\
\hline AFW & 166 & $23.3 \%$ & 1 & & 1 & & & & & & 2 & 1 & & & & 1 & & 6 & $14.3 \%$ \\
\hline $\mathrm{CCW}$ & 141 & $19.8 \%$ & 1 & & & & & & & & & & 1 & & & & & 2 & $4.8 \%$ \\
\hline RCS & 57 & $8.0 \%$ & & & & & & & & & & & & & 1 & & & 1 & $2.4 \%$ \\
\hline RHR & 133 & $18.7 \%$ & 1 & 1 & & & 1 & & & & & & 1 & & & & 1 & 5 & $11.9 \%$ \\
\hline SWN & 215 & $30.2 \%$ & & 2 & 5 & 2 & 1 & 3 & 2 & 4 & & 1 & 1 & 2 & 3 & 1 & 1 & 28 & $66.7 \%$ \\
\hline Total & 712 & $100 \%$ & 3 & 3 & 6 & 2 & 2 & 3 & 2 & 4 & 2 & 2 & 3 & 2 & 4 & 2 & 2 & 42 & $100 \%$ \\
\hline
\end{tabular}

Table 8 . Summary of AOV failure counts for the SO failure mode over time by system $>20$ demands per year.

\begin{tabular}{|c|c|c|c|c|c|c|c|c|c|c|c|c|c|c|c|c|c|c|c|}
\hline $\begin{array}{c}\text { System } \\
\text { Code }\end{array}$ & $\begin{array}{l}\text { Valve } \\
\text { Count }\end{array}$ & $\begin{array}{l}\text { Valve } \\
\text { Percent }\end{array}$ & FY-98 & FY-99 & FY-00 & FY-01 & FY-02 & FY-03 & FY-04 & FY-05 & FY-06 & FY-07 & FY-08 & FY-09 & FY-10 & FY-11 & FY-12 & Total & $\begin{array}{c}\text { Percent } \\
\text { of } \\
\text { Failures }\end{array}$ \\
\hline AFW & 166 & $25.3 \%$ & & & & 1 & & & & 1 & & & & & 1 & & & 3 & $16.7 \%$ \\
\hline $\mathrm{CCW}$ & 141 & $21.5 \%$ & & 1 & & & & & & & & & & & & & 1 & 2 & $11.1 \%$ \\
\hline $\mathrm{RCl}$ & 2 & $0.3 \%$ & & & & & & & & & & & 1 & & & & & 1 & $5.6 \%$ \\
\hline RHR & 133 & $20.2 \%$ & 2 & & & & & & & & & & 1 & & & & & 3 & $16.7 \%$ \\
\hline SWN & 215 & $32.7 \%$ & 1 & 2 & & 2 & 1 & & & & 1 & & & 2 & & & & 9 & $50.0 \%$ \\
\hline Total & 657 & $100 \%$ & 3 & 3 & & 3 & 1 & & & 1 & 1 & & 2 & 2 & 1 & & 1 & 18 & $100 \%$ \\
\hline
\end{tabular}




\subsection{AOV Engineering Analysis by Failure Modes}

The engineering analysis of AOV failure sub-components, causes, detection methods, and recovery are presented in this section. Each analysis first divides the events into two categories: AOVs with $\leq 20$ demands/yr [Low-Demands] and AOVs with $>20$ demands/yr [High-Demands].

The second division of the events is by the failure mode determined after EPIX data review by the staff. See Section 5 for more description of failure modes.

AOV sub-component contributions to the three failure modes are presented in Figure 15. The subcomponent contributions are similar to those used in the CCF database. For all three failure modes, the actuator is the largest contributor to the failure rates/probabilities.

AOV cause group contributions to the three failure modes are presented in Figure 16. The cause groups are similar to those used in the CCF database. Table 9 shows the breakdown of the cause groups with the specific causes that were coded during the data collection. The most likely cause for the FTOC and FTOP failure modes is grouped as Internal. Internal means that the cause was related to something within the AOV component such as a worn out part or the normal internal environment. The second most likely cause for the FTOC and FTOP failure mode is grouped as Human, which includes human action, procedures and maintenance. The most likely cause for the SO failure mode is grouped as Human or Design. Of particular interest is the Human cause group.

AOV detection methods to the three failure modes are presented in Figure 17. Note that there are differences between the Low-Demand and High-Demand detection methods.

Low-Demand - the most likely detection method for FTOC is a testing demand. The most likely detection method for FTOP and SO is an actual demand.

High-Demand - the most likely detection method for FTOC is a non-test demand followed by testing. The most likely detection method for FTOP and SO is an actual demand.

AOV recovery to the three failure modes are presented in Figure 18. The overall non-recoverable to recoverable ratio is approximately $7: 1$. 
Table 9. Component failure cause groups.

\begin{tabular}{|c|c|c|}
\hline Group & Specific Cause & Description \\
\hline Design & $\begin{array}{l}\text { Construction/installation } \\
\text { error or inadequacy }\end{array}$ & $\begin{array}{l}\text { Used when a construction or installation error is made during } \\
\text { the original or modification installation. This includes } \\
\text { specification of incorrect component or material. }\end{array}$ \\
\hline Design & Design error or inadequacy & Used when a design error is made. \\
\hline Design & $\begin{array}{l}\text { Manufacturing error or } \\
\text { inadequacy }\end{array}$ & $\begin{array}{l}\text { Used when a manufacturing error is made during component } \\
\text { manufacture. }\end{array}$ \\
\hline External & State of other component & $\begin{array}{l}\text { Used when the cause of a failure is the result of a component } \\
\text { state that is not associated with the component that failed. } \\
\text { An example would be the diesel failed due to no fuel in the } \\
\text { fuel storage tanks. }\end{array}$ \\
\hline External & $\begin{array}{l}\text { Ambient environmental } \\
\text { stress }\end{array}$ & $\begin{array}{l}\text { Used when the cause of a failure is the result of an } \\
\text { environmental condition from the location of the component. }\end{array}$ \\
\hline Human & $\begin{array}{l}\text { Accidental action } \\
\text { (unintentional or undesired } \\
\text { human errors) }\end{array}$ & $\begin{array}{l}\text { Used when a human error (during the performance of an } \\
\text { activity) results in an unintentional or undesired action. }\end{array}$ \\
\hline Human & Human action procedure & $\begin{array}{l}\text { Used when the procedure is not followed or the procedure is } \\
\text { incorrect. For example: when a missed step or incorrect step } \\
\text { in a surveillance procedure results in a component failure. }\end{array}$ \\
\hline Human & Inadequate maintenance & $\begin{array}{l}\text { Used when a human error (during the performance of } \\
\text { maintenance) results in an unintentional or undesired action. }\end{array}$ \\
\hline Internal & $\begin{array}{l}\text { Internal to component, } \\
\text { piece-part }\end{array}$ & $\begin{array}{l}\text { Used when the cause of a failure is a non-specific result of a } \\
\text { failure internal to the component that failed other than aging } \\
\text { or wear. }\end{array}$ \\
\hline Internal & Internal environment & $\begin{array}{l}\text { The internal environment led to the failure. Debris/Foreign } \\
\text { material as well as an operating medium chemistry issue. }\end{array}$ \\
\hline Internal & Setpoint drift & $\begin{array}{l}\text { Used when the cause of a failure is the result of setpoint drift } \\
\text { or adjustment. }\end{array}$ \\
\hline Internal & Age/Wear & $\begin{array}{l}\text { Used when the cause of the failure is a non-specific aging or } \\
\text { wear issue. }\end{array}$ \\
\hline Other & Unknown & Used when the cause of the failure is not known. \\
\hline Other & $\begin{array}{l}\text { Other (stated cause does } \\
\text { not fit other categories) }\end{array}$ & $\begin{array}{l}\text { Used when the cause of a failure is provided but it does not } \\
\text { meet any one of the descriptions. }\end{array}$ \\
\hline Procedure & Inadequate procedure & $\begin{array}{l}\text { Used when the cause of a failure is the result of an } \\
\text { inadequate procedure operating or maintenance. }\end{array}$ \\
\hline
\end{tabular}



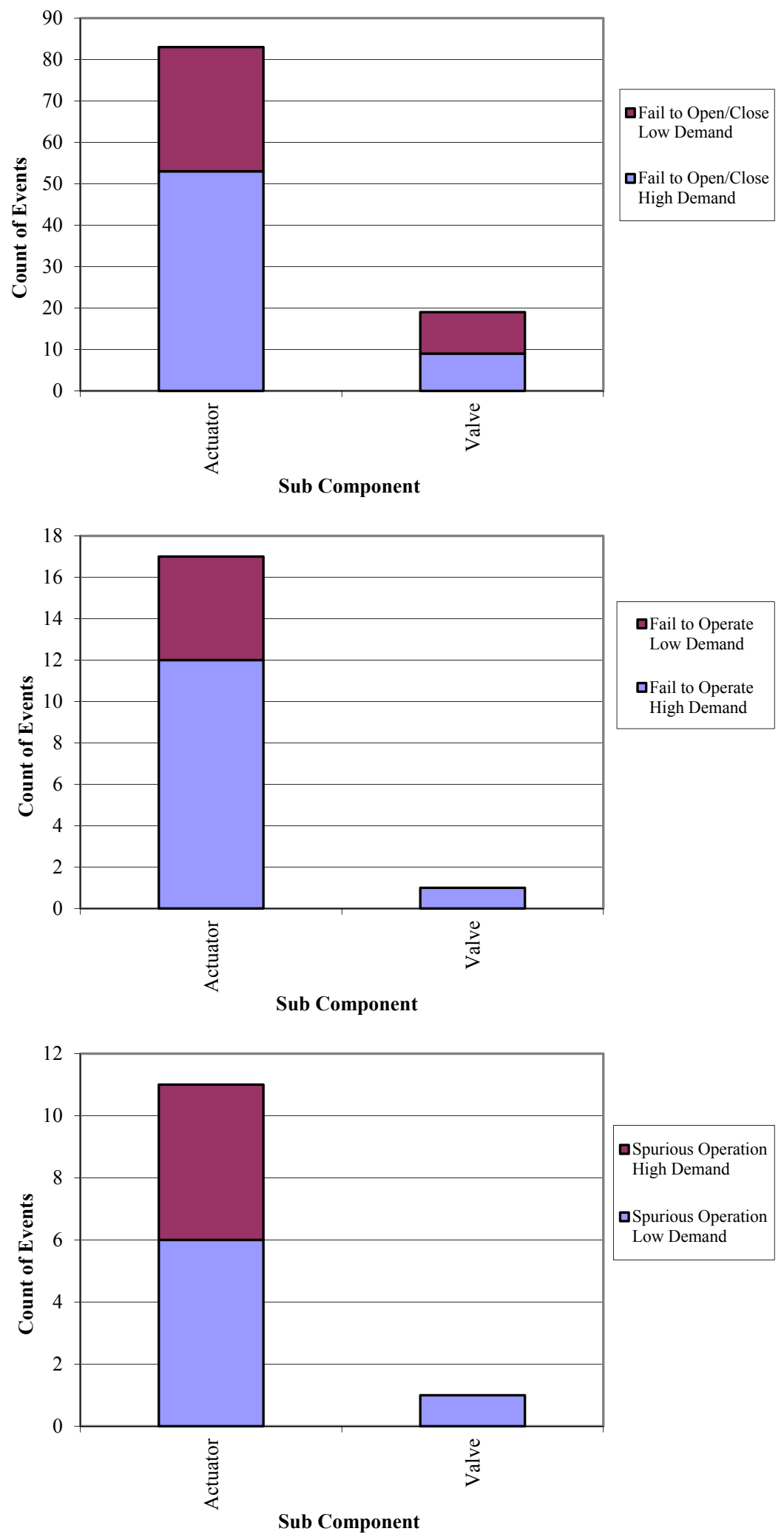

Figure 15. AOV failure breakdown by period, sub component, and failure mode. 


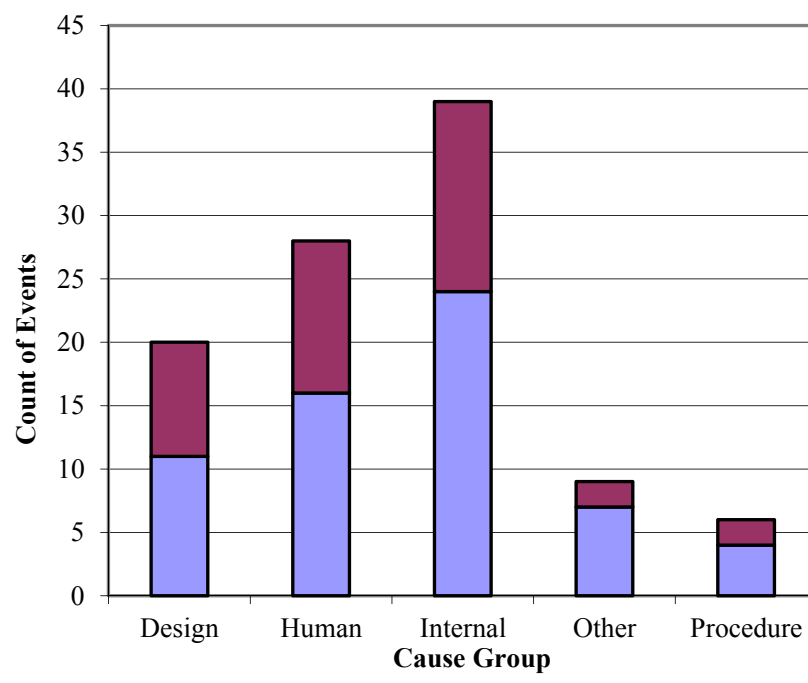

口Fail to Open/Close Low Demand

口Fail to Open/Close High Demand

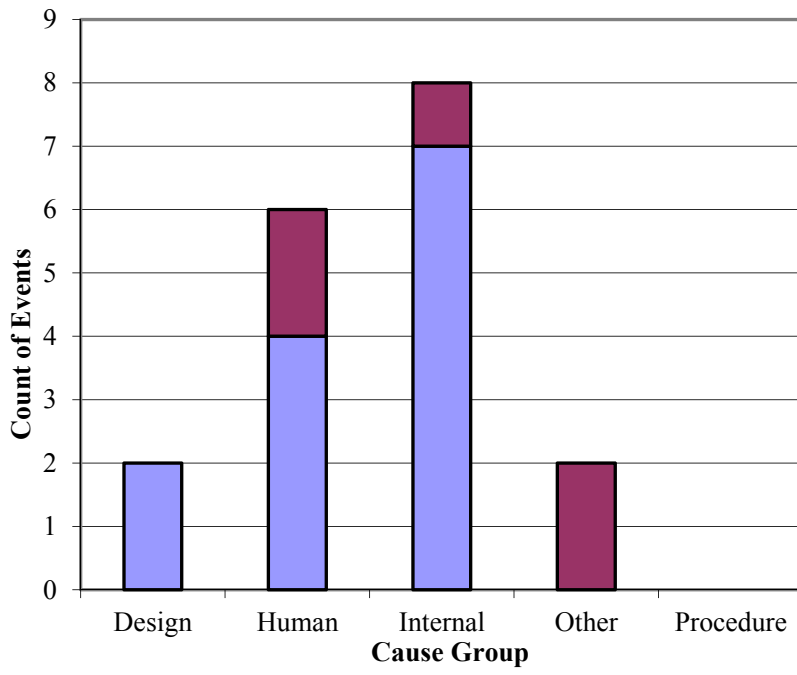

Fail to Operate Low Demand

口Fail to Operate High Demand

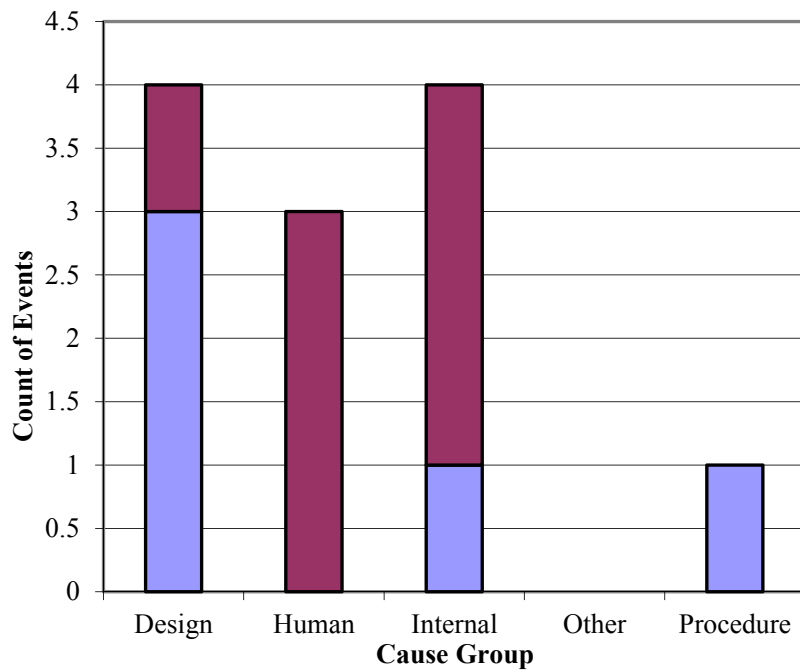

口Spurious Operation Low Demand

口Spurious Operation High Demand

Figure 16. AOV breakdown by time period, cause group, and failure mode. 

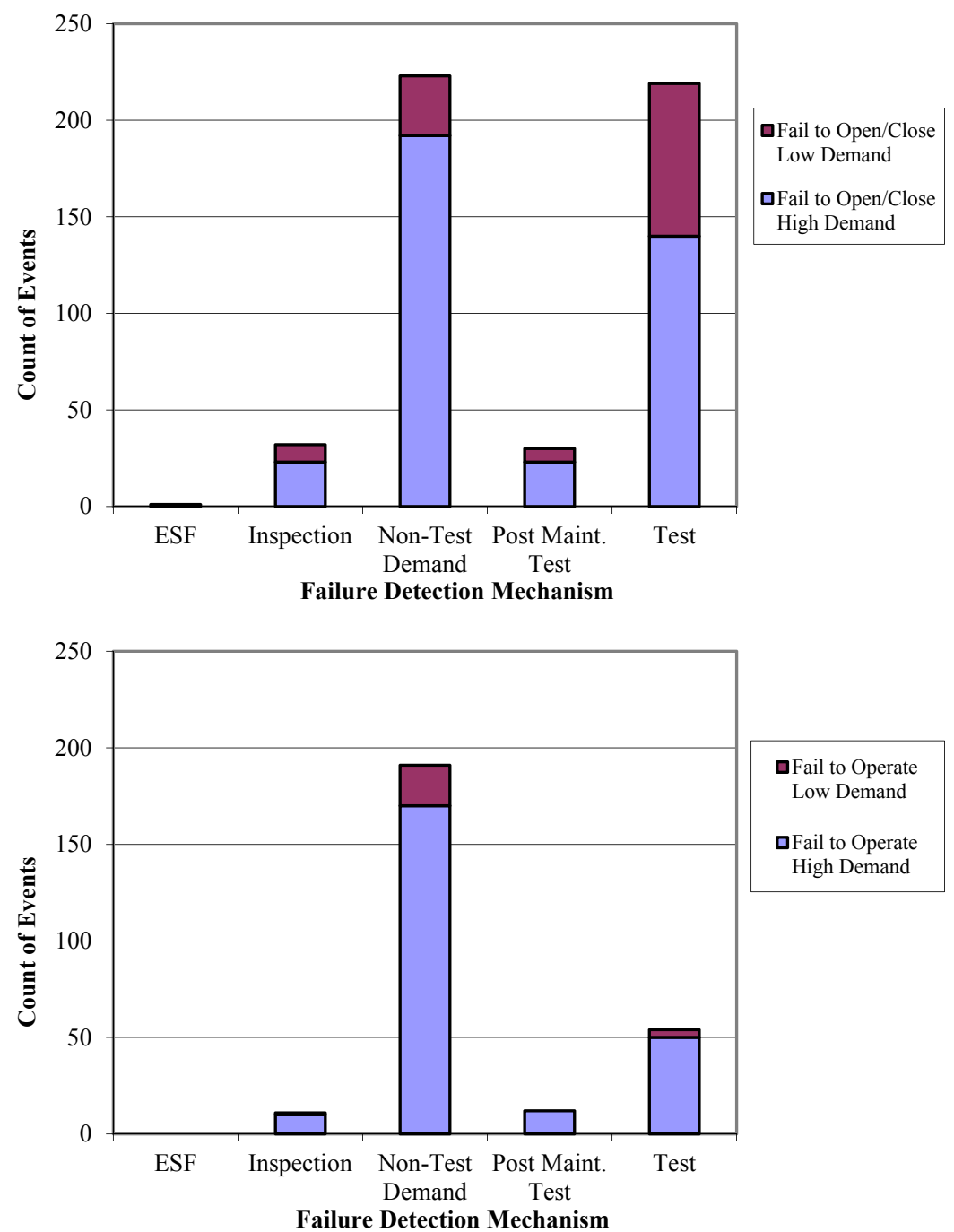

口Fail to Operate Low Demand

口Fail to Operate High Demand

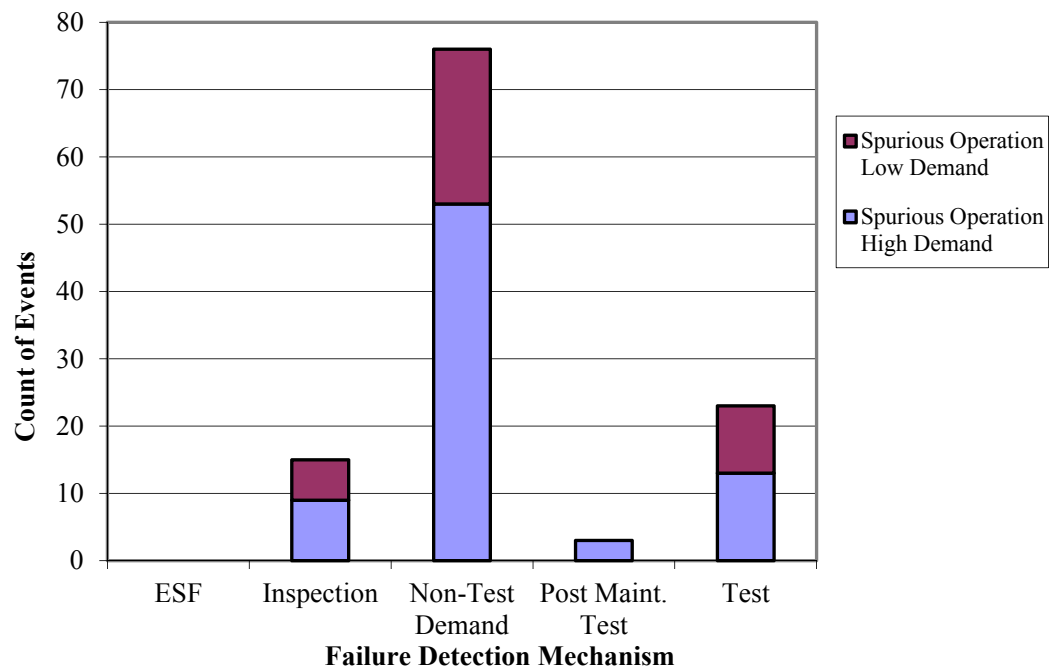

Figure 17. AOV component failure distribution by period, failure mode, and method of detection. 

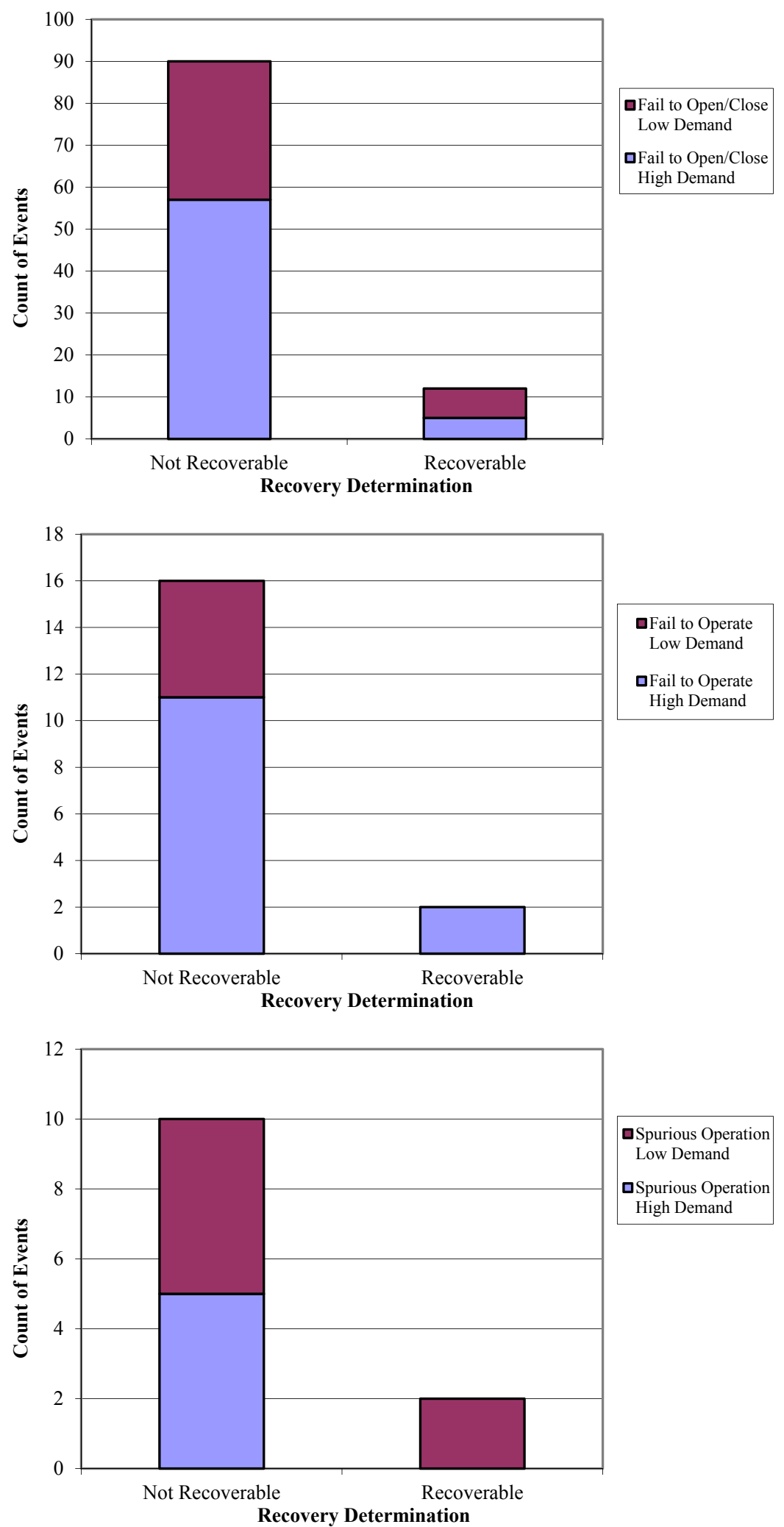

Figure 18. AOV component failure distribution by period, failure mode, and recovery. 


\section{AOV ASSEMBLY DESCRIPTION}

An AOV assembly consists of a valve body and pneumatic operator sub-components. The valve body is generally a globe or butterfly type. The pneumatic operator is generally a piston or diaphragm type actuator. Main steam isolation valves and power operated relief valves are excluded from the AOV study even though pneumatically operated, as these are valves with different design and operating features.

The piece-parts of the valve body are the stem, packing, and internals. The pneumatic operator pieceparts may include piston internals/seals or diaphragm, positioner, mechanical linkage, volume booster, pilot valve, bolting, air regulator, airline, and wiring/contacts. Failures associated with instrument air systems that are not integral to the AOV assembly (e.g., contamination from the instrument air system that failed the AOV) are excluded in the AOV analysis.

Failure modes for the AOV include FTOC, which combines the fail to open and fail to close failure modes into a single category; FTOP, which is a rate-based failure mode that includes fail to control for a flow/temperature control device and any other rate-based failure modes not including spurious operation; and SO, which includes spurious opening and spurious closing. 


\section{DATA TABLES}

Table 10. Plot data for industry-wide AOV FTOC trend with $\leq 20$ demands per year. Figure 1

\begin{tabular}{|c|c|c|c|c|c|c|c|c|}
\hline \multirow[b]{2}{*}{$\begin{array}{c}\text { FYI } \\
\text { Source }\end{array}$} & \multirow[b]{2}{*}{ Failures } & \multirow[b]{2}{*}{ Demands } & \multicolumn{3}{|c|}{ Regression Curve Data Points } & \multicolumn{3}{|c|}{ Plot Trend Error Bar Points } \\
\hline & & & Mean & $\begin{array}{c}\text { Lower } \\
(5 \%)\end{array}$ & $\begin{array}{l}\text { Upper } \\
(95 \%)\end{array}$ & $\begin{array}{c}\text { Lower } \\
(5 \%)\end{array}$ & $\begin{array}{l}\text { Upper } \\
(95 \%)\end{array}$ & Mean \\
\hline \multicolumn{2}{|c|}{ Update 2010} & & & & & $6.27 \mathrm{E}-05$ & $2.74 \mathrm{E}-03$ & $9.51 \mathrm{E}-04$ \\
\hline 1998 & 10 & $8,284.2$ & & & & $6.52 \mathrm{E}-04$ & $1.98 \mathrm{E}-03$ & $1.18 \mathrm{E}-03$ \\
\hline 1999 & 8 & $8,371.0$ & & & & 4.83E-04 & $1.68 \mathrm{E}-03$ & $9.47 \mathrm{E}-04$ \\
\hline 2000 & 5 & $8,231.5$ & & & & $2.59 \mathrm{E}-04$ & $1.27 \mathrm{E}-03$ & $6.23 E-04$ \\
\hline 2001 & 8 & $8,425.5$ & & & & $4.80 \mathrm{E}-04$ & 1.67E-03 & $9.42 \mathrm{E}-04$ \\
\hline 2002 & 7 & $8,464.3$ & & & & $4.01 \mathrm{E}-04$ & $1.52 \mathrm{E}-03$ & 8.27E-04 \\
\hline 2003 & 9 & $8,506.7$ & $8.32 \mathrm{E}-04$ & $4.86 \mathrm{E}-04$ & $1.42 \mathrm{E}-03$ & $5.56 \mathrm{E}-04$ & $1.79 \mathrm{E}-03$ & $1.04 \mathrm{E}-03$ \\
\hline 2004 & 6 & $8,592.2$ & $8.20 E-04$ & $5.20 E-04$ & $1.29 \mathrm{E}-03$ & $3.20 \mathrm{E}-04$ & $1.36 \mathrm{E}-03$ & 7.07E-04 \\
\hline 2005 & 5 & $8,649.1$ & $8.08 \mathrm{E}-04$ & $5.51 \mathrm{E}-04$ & $1.18 \mathrm{E}-03$ & 2.47E-04 & $1.21 \mathrm{E}-03$ & $5.95 \mathrm{E}-04$ \\
\hline 2006 & 8 & $8,052.8$ & $7.96 \mathrm{E}-04$ & $5.73 E-04$ & $1.10 \mathrm{E}-03$ & $5.01 \mathrm{E}-04$ & $1.74 \mathrm{E}-03$ & $9.82 \mathrm{E}-04$ \\
\hline 2007 & 6 & $8,095.6$ & $7.84 \mathrm{E}-04$ & $5.81 \mathrm{E}-04$ & $1.06 \mathrm{E}-03$ & $3.39 \mathrm{E}-04$ & $1.44 \mathrm{E}-03$ & 7.47E-04 \\
\hline 2008 & 6 & $8,056.5$ & $7.72 \mathrm{E}-04$ & $5.69 E-04$ & 1.05E-03 & $3.40 \mathrm{E}-04$ & $1.44 \mathrm{E}-03$ & $7.51 \mathrm{E}-04$ \\
\hline 2009 & 5 & $8,003.9$ & $7.61 \mathrm{E}-04$ & $5.40 \mathrm{E}-04$ & $1.07 \mathrm{E}-03$ & $2.66 \mathrm{E}-04$ & $1.30 \mathrm{E}-03$ & $6.39 \mathrm{E}-04$ \\
\hline 2010 & 7 & $8,137.0$ & $7.50 \mathrm{E}-04$ & $5.00 \mathrm{E}-04$ & $1.12 \mathrm{E}-03$ & 4.16E-04 & $1.58 \mathrm{E}-03$ & $8.58 \mathrm{E}-04$ \\
\hline 2011 & 13 & $8,024.7$ & $7.39 \mathrm{E}-04$ & 4.57E-04 & 1.19E-03 & $9.37 \mathrm{E}-04$ & $2.47 \mathrm{E}-03$ & $1.57 \mathrm{E}-03$ \\
\hline 2012 & 3 & $8,131.5$ & $7.28 \mathrm{E}-04$ & $4.14 \mathrm{E}-04$ & $1.28 \mathrm{E}-03$ & $1.24 \mathrm{E}-04$ & $9.68 \mathrm{E}-04$ & $4.01 \mathrm{E}-04$ \\
\hline Total & 106 & $124,026.5$ & & & & & & \\
\hline
\end{tabular}


Table 11. Plot data for industry-wide AOV FTOC trend with $>20$ demands per year. Figure 2

\begin{tabular}{|c|c|c|c|c|c|c|c|c|}
\hline \multirow[b]{2}{*}{$\begin{array}{c}\text { FYI } \\
\text { Source }\end{array}$} & \multirow[b]{2}{*}{ Failures } & \multirow[b]{2}{*}{ Demands } & \multicolumn{3}{|c|}{ Regression Curve Data Points } & \multicolumn{3}{|c|}{ Plot Trend Error Bar Points } \\
\hline & & & Mean & $\begin{array}{c}\text { Lower } \\
(5 \%)\end{array}$ & $\begin{array}{l}\text { Upper } \\
\text { (95\%) }\end{array}$ & $\begin{array}{l}\text { Lower } \\
(5 \%)\end{array}$ & $\begin{array}{l}\text { Upper } \\
\text { (95\%) }\end{array}$ & Mean \\
\hline \multicolumn{2}{|c|}{ Update 2010} & & & & & $6.27 \mathrm{E}-05$ & $2.74 \mathrm{E}-03$ & $9.51 \mathrm{E}-04$ \\
\hline 1998 & 12 & $26,651.6$ & & & & $2.53 E-04$ & $6.95 \mathrm{E}-04$ & 4.33E-04 \\
\hline 1999 & 10 & $28,626.8$ & & & & $1.88 \mathrm{E}-04$ & $5.71 \mathrm{E}-04$ & $3.41 \mathrm{E}-04$ \\
\hline 2000 & 7 & $27,878.7$ & & & & $1.21 \mathrm{E}-04$ & $4.59 \mathrm{E}-04$ & $2.49 E-04$ \\
\hline 2001 & 11 & $27,216.8$ & & & & $2.23 E-04$ & $6.40 \mathrm{E}-04$ & $3.91 \mathrm{E}-04$ \\
\hline 2002 & 5 & $27,533.2$ & & & & 7.70E-05 & $3.76 \mathrm{E}-04$ & $1.85 E-04$ \\
\hline 2003 & 7 & $27,825.5$ & $2.35 \mathrm{E}-04$ & 1.34E-04 & 4.14E-04 & $1.21 \mathrm{E}-04$ & $4.60 \mathrm{E}-04$ & $2.50 E-04$ \\
\hline 2004 & 8 & $27,270.1$ & $2.31 \mathrm{E}-04$ & $1.43 \mathrm{E}-04$ & $3.72 \mathrm{E}-04$ & $1.47 \mathrm{E}-04$ & $5.12 \mathrm{E}-04$ & $2.89 E-04$ \\
\hline 2005 & 6 & $27,599.5$ & $2.26 \mathrm{E}-04$ & $1.51 \mathrm{E}-04$ & $3.38 \mathrm{E}-04$ & $9.89 \mathrm{E}-05$ & $4.20 \mathrm{E}-04$ & $2.18 \mathrm{E}-04$ \\
\hline 2006 & 7 & $27,332.6$ & $2.22 \mathrm{E}-04$ & $1.57 \mathrm{E}-04$ & 3.13E-04 & $1.23 E-04$ & $4.67 \mathrm{E}-04$ & $2.54 \mathrm{E}-04$ \\
\hline 2007 & 2 & $27,892.2$ & $2.18 \mathrm{E}-04$ & $1.59 \mathrm{E}-04$ & $2.98 \mathrm{E}-04$ & $1.90 \mathrm{E}-05$ & $2.34 \mathrm{E}-04$ & $8.31 \mathrm{E}-05$ \\
\hline 2008 & 7 & $27,759.2$ & $2.13 E-04$ & $1.55 \mathrm{E}-04$ & 2.93E-04 & $1.21 \mathrm{E}-04$ & 4.61E-04 & $2.50 E-04$ \\
\hline 2009 & 7 & $27,106.6$ & $2.09 E-04$ & 1.46E-04 & $3.00 \mathrm{E}-04$ & $1.24 \mathrm{E}-04$ & 4.71E-04 & $2.56 \mathrm{E}-04$ \\
\hline 2010 & 7 & $27,052.1$ & $2.05 \mathrm{E}-04$ & $1.34 \mathrm{E}-04$ & $3.13 \mathrm{E}-04$ & $1.24 \mathrm{E}-04$ & $4.72 \mathrm{E}-04$ & $2.56 \mathrm{E}-04$ \\
\hline 2011 & 7 & $27,048.6$ & $2.01 \mathrm{E}-04$ & $1.22 \mathrm{E}-04$ & 3.33E-04 & $1.24 \mathrm{E}-04$ & 4.72E-04 & $2.57 E-04$ \\
\hline 2012 & 4 & $26,661.9$ & 1.97E-04 & $1.09 \mathrm{E}-04$ & 3.57E-04 & 5.76E-05 & $3.41 \mathrm{E}-04$ & $1.56 \mathrm{E}-04$ \\
\hline Total & 107 & $411,455.5$ & & & & & & \\
\hline
\end{tabular}

Table 12. Plot data for industry-wide AOV FTOP trend with $\leq 20$ demands per year. Figure 3

\begin{tabular}{|c|c|c|c|c|c|c|c|c|}
\hline \multirow[b]{2}{*}{$\begin{array}{c}\text { FYI } \\
\text { Source }\end{array}$} & \multirow[b]{2}{*}{ Failures } & \multirow[b]{2}{*}{ Hours } & \multicolumn{3}{|c|}{ Regression Curve Data Points } & \multicolumn{3}{|c|}{ Plot Trend Error Bar Points } \\
\hline & & & Mean & $\begin{array}{c}\text { Lower } \\
(5 \%)\end{array}$ & $\begin{array}{l}\text { Upper } \\
(95 \%)\end{array}$ & $\begin{array}{c}\text { Lower } \\
(5 \%)\end{array}$ & $\begin{array}{l}\text { Upper } \\
(95 \%)\end{array}$ & Mean \\
\hline \multicolumn{2}{|c|}{ Update 2010} & & & & & $2.66 \mathrm{E}-08$ & $6.59 \mathrm{E}-07$ & $2.49 \mathrm{E}-07$ \\
\hline 1998 & 0 & $10,231,680.0$ & & & & $1.25 \mathrm{E}-10$ & $2.49 \mathrm{E}-07$ & $3.19 \mathrm{E}-08$ \\
\hline 1999 & 3 & $10,205,400.0$ & & & & $6.93 \mathrm{E}-08$ & $5.41 \mathrm{E}-07$ & $2.24 \mathrm{E}-07$ \\
\hline 2000 & 1 & $10,249,200.0$ & & & & 1.12E-08 & $3.53 \mathrm{E}-07$ & $9.56 \mathrm{E}-08$ \\
\hline 2001 & 3 & $10,301,760.0$ & & & & $6.88 \mathrm{E}-08$ & 5.37E-07 & $2.22 \mathrm{E}-07$ \\
\hline 2002 & 2 & $10,301,760.0$ & & & & $3.64 \mathrm{E}-08$ & 4.47E-07 & $1.59 \mathrm{E}-07$ \\
\hline 2003 & 1 & $10,310,520.0$ & $5.76 \mathrm{E}-08$ & $2.23 \mathrm{E}-08$ & $1.49 \mathrm{E}-07$ & $1.12 \mathrm{E}-08$ & $3.51 \mathrm{E}-07$ & $9.52 \mathrm{E}-08$ \\
\hline 2004 & 0 & $10,319,280.0$ & $6.12 \mathrm{E}-08$ & $2.73 \mathrm{E}-08$ & $1.37 \mathrm{E}-07$ & $1.25 \mathrm{E}-10$ & $2.48 \mathrm{E}-07$ & $3.17 \mathrm{E}-08$ \\
\hline 2005 & 2 & $10,319,280.0$ & $6.50 \mathrm{E}-08$ & $3.30 \mathrm{E}-08$ & $1.28 \mathrm{E}-07$ & $3.63 E-08$ & $4.46 \mathrm{E}-07$ & $1.59 \mathrm{E}-07$ \\
\hline 2006 & 0 & $10,380,600.0$ & $6.91 \mathrm{E}-08$ & $3.89 \mathrm{E}-08$ & $1.23 \mathrm{E}-07$ & $1.24 \mathrm{E}-10$ & $2.47 \mathrm{E}-07$ & $3.16 \mathrm{E}-08$ \\
\hline 2007 & 0 & $10,310,520.0$ & 7.35E-08 & $4.40 \mathrm{E}-08$ & $1.23 \mathrm{E}-07$ & $1.25 \mathrm{E}-10$ & $2.48 \mathrm{E}-07$ & $3.17 \mathrm{E}-08$ \\
\hline 2008 & 2 & $10,319,280.0$ & 7.81E-08 & $4.71 \mathrm{E}-08$ & $1.30 \mathrm{E}-07$ & 3.63E-08 & $4.46 \mathrm{E}-07$ & $1.59 \mathrm{E}-07$ \\
\hline 2009 & 1 & $10,301,760.0$ & 8.30E-08 & $4.75 \mathrm{E}-08$ & $1.45 \mathrm{E}-07$ & 1.12E-08 & $3.52 \mathrm{E}-07$ & $9.53 \mathrm{E}-08$ \\
\hline 2010 & 1 & $10,301,760.0$ & $8.82 \mathrm{E}-08$ & $4.60 \mathrm{E}-08$ & $1.69 \mathrm{E}-07$ & 1.12E-08 & $3.52 \mathrm{E}-07$ & $9.53 \mathrm{E}-08$ \\
\hline 2011 & 1 & $10,459,440.0$ & $9.38 \mathrm{E}-08$ & 4.32E-08 & $2.04 \mathrm{E}-07$ & $1.11 \mathrm{E}-08$ & $3.48 \mathrm{E}-07$ & $9.43 E-08$ \\
\hline 2012 & 1 & $10,363,080.0$ & 9.97E-08 & $3.99 \mathrm{E}-08$ & $2.49 \mathrm{E}-07$ & $1.11 \mathrm{E}-08$ & $3.50 \mathrm{E}-07$ & $9.49 E-08$ \\
\hline Total & 18 & $154,675,320.0$ & & & & & & \\
\hline
\end{tabular}


Table 13. Plot data for industry-wide AOV FTOP trend with $>20$ demands per year. Figure 4

\begin{tabular}{|c|c|c|c|c|c|c|c|c|}
\hline \multirow[b]{2}{*}{$\begin{array}{c}\text { FYI } \\
\text { Source }\end{array}$} & \multirow[b]{2}{*}{ Failures } & \multirow[b]{2}{*}{ Hours } & \multicolumn{3}{|c|}{ Regression Curve Data Points } & \multicolumn{3}{|c|}{ Plot Trend Error Bar Points } \\
\hline & & & Mean & $\begin{array}{c}\text { Lower } \\
(5 \%)\end{array}$ & $\begin{array}{l}\text { Upper } \\
(95 \%)\end{array}$ & $\begin{array}{c}\text { Lower } \\
(5 \%)\end{array}$ & $\begin{array}{l}\text { Upper } \\
(95 \%)\end{array}$ & Mean \\
\hline Upda & e 2010 & & & & & $2.66 \mathrm{E}-08$ & $6.59 \mathrm{E}-07$ & $2.49 \mathrm{E}-07$ \\
\hline 1998 & 3 & $7,507,320.0$ & & & & $1.22 \mathrm{E}-07$ & $9.50 \mathrm{E}-07$ & $3.93 \mathrm{E}-07$ \\
\hline 1999 & 3 & $7,533,600.0$ & & & & $1.21 \mathrm{E}-07$ & $9.47 \mathrm{E}-07$ & $3.92 E-07$ \\
\hline 2000 & 6 & $7,551,120.0$ & & & & $3.29 \mathrm{E}-07$ & $1.40 \mathrm{E}-06$ & $7.26 \mathrm{E}-07$ \\
\hline 2001 & 2 & $7,454,760.0$ & & & & $6.47 \mathrm{E}-08$ & $7.94 \mathrm{E}-07$ & $2.82 E-07$ \\
\hline 2002 & 2 & $7,507,320.0$ & & & & $6.43 \mathrm{E}-08$ & $7.90 \mathrm{E}-07$ & 2.81E-07 \\
\hline 2003 & 3 & $7,472,280.0$ & $3.63 \mathrm{E}-07$ & $2.48 \mathrm{E}-07$ & $5.31 \mathrm{E}-07$ & $1.22 \mathrm{E}-07$ & $9.53 \mathrm{E}-07$ & $3.94 \mathrm{E}-07$ \\
\hline 2004 & 2 & $7,472,280.0$ & $3.58 \mathrm{E}-07$ & $2.59 E-07$ & $4.94 \mathrm{E}-07$ & $6.46 \mathrm{E}-08$ & 7.93E-07 & $2.82 \mathrm{E}-07$ \\
\hline 2005 & 4 & $7,481,040.0$ & $3.53 \mathrm{E}-07$ & 2.69E-07 & 4.63E-07 & $1.87 \mathrm{E}-07$ & $1.11 \mathrm{E}-06$ & $5.07 \mathrm{E}-07$ \\
\hline 2006 & 2 & $7,446,000.0$ & $3.48 \mathrm{E}-07$ & $2.76 \mathrm{E}-07$ & 4.39E-07 & $6.47 \mathrm{E}-08$ & $7.95 \mathrm{E}-07$ & 2.83E-07 \\
\hline 2007 & 2 & $7,446,000.0$ & $3.43 \mathrm{E}-07$ & $2.78 \mathrm{E}-07$ & $4.24 \mathrm{E}-07$ & $6.47 \mathrm{E}-08$ & $7.95 \mathrm{E}-07$ & 2.83E-07 \\
\hline 2008 & 3 & $7,463,520.0$ & $3.39 \mathrm{E}-07$ & $2.74 \mathrm{E}-07$ & 4.19E-07 & $1.22 \mathrm{E}-07$ & $9.54 \mathrm{E}-07$ & $3.95 \mathrm{E}-07$ \\
\hline 2009 & 2 & $7,446,000.0$ & $3.34 \mathrm{E}-07$ & $2.63 E-07$ & 4.23E-07 & $6.47 E-08$ & $7.95 E-07$ & 2.83E-07 \\
\hline 2010 & 4 & $7,349,640.0$ & $3.29 \mathrm{E}-07$ & $2.49 \mathrm{E}-07$ & $4.36 \mathrm{E}-07$ & $1.90 \mathrm{E}-07$ & 1.12E-06 & $5.14 \mathrm{E}-07$ \\
\hline 2011 & 2 & $7,367,160.0$ & $3.25 \mathrm{E}-07$ & $2.33 E-07$ & $4.53 \mathrm{E}-07$ & $6.53 \mathrm{E}-08$ & $8.02 \mathrm{E}-07$ & $2.85 \mathrm{E}-07$ \\
\hline 2012 & 2 & $7,253,280.0$ & $3.20 \mathrm{E}-07$ & 2.16E-07 & $4.74 \mathrm{E}-07$ & $6.62 \mathrm{E}-08$ & $8.13 E-07$ & 2.89E-07 \\
\hline Total & 42 & $111,751,320.0$ & & & & & & \\
\hline
\end{tabular}

Table 14. Plot data for industry-wide AOV SO trend with $\leq 20$ demands per year. Figure 5

\begin{tabular}{|c|c|c|c|c|c|c|c|c|}
\hline \multirow[b]{2}{*}{$\begin{array}{c}\text { FYI } \\
\text { Source }\end{array}$} & \multirow[b]{2}{*}{ Failures } & \multirow[b]{2}{*}{ Hours } & \multicolumn{3}{|c|}{ Regression Curve Data Points } & \multicolumn{3}{|c|}{ Plot Trend Error Bar Points } \\
\hline & & & Mean & $\begin{array}{c}\text { Lower } \\
(5 \%)\end{array}$ & $\begin{array}{l}\text { Upper } \\
(95 \%)\end{array}$ & $\begin{array}{c}\text { Lower } \\
(5 \%)\end{array}$ & $\begin{array}{l}\text { Upper } \\
(95 \%)\end{array}$ & Mean \\
\hline Upda & 2010 & & & & & $2.04 \mathrm{E}-09$ & 4.49E-07 & $1.31 \mathrm{E}-07$ \\
\hline 1998 & 0 & $10,231,680.0$ & & & & $1.47 \mathrm{E}-10$ & $2.92 \mathrm{E}-07$ & $3.74 \mathrm{E}-08$ \\
\hline 1999 & 6 & $10,205,400.0$ & & & & $2.21 \mathrm{E}-07$ & $9.37 E-07$ & 4.87E-07 \\
\hline 2000 & 1 & $10,249,200.0$ & & & & $1.31 \mathrm{E}-08$ & 4.14E-07 & $1.12 \mathrm{E}-07$ \\
\hline 2001 & 1 & $10,301,760.0$ & & & & $1.31 \mathrm{E}-08$ & $4.12 \mathrm{E}-07$ & $1.12 \mathrm{E}-07$ \\
\hline 2002 & 8 & $10,301,760.0$ & & & & $3.23 \mathrm{E}-07$ & $1.12 \mathrm{E}-06$ & $6.33 E-07$ \\
\hline 2003 & 2 & $10,310,520.0$ & $9.53 E-08$ & $4.09 \mathrm{E}-08$ & $2.22 \mathrm{E}-07$ & $4.26 \mathrm{E}-08$ & $5.23 \mathrm{E}-07$ & $1.86 \mathrm{E}-07$ \\
\hline 2004 & 1 & $10,319,280.0$ & $1.03 E-07$ & $5.03 E-08$ & 2.13E-07 & $1.31 \mathrm{E}-08$ & $4.11 \mathrm{E}-07$ & $1.12 \mathrm{E}-07$ \\
\hline 2005 & 1 & $10,319,280.0$ & $1.12 \mathrm{E}-07$ & $6.12 \mathrm{E}-08$ & $2.06 \mathrm{E}-07$ & $1.31 \mathrm{E}-08$ & $4.11 \mathrm{E}-07$ & $1.12 \mathrm{E}-07$ \\
\hline 2006 & 0 & $10,380,600.0$ & $1.22 \mathrm{E}-07$ & $7.30 \mathrm{E}-08$ & $2.04 \mathrm{E}-07$ & $1.45 \mathrm{E}-10$ & $2.89 E-07$ & $3.70 E-08$ \\
\hline 2007 & 2 & $10,310,520.0$ & $1.32 \mathrm{E}-07$ & $8.44 \mathrm{E}-08$ & $2.08 \mathrm{E}-07$ & 4.26E-08 & $5.23 \mathrm{E}-07$ & $1.86 \mathrm{E}-07$ \\
\hline 2008 & 2 & $10,319,280.0$ & $1.44 \mathrm{E}-07$ & $9.32 \mathrm{E}-08$ & $2.22 \mathrm{E}-07$ & $4.26 \mathrm{E}-08$ & $5.23 \mathrm{E}-07$ & $1.86 \mathrm{E}-07$ \\
\hline 2009 & 1 & $10,301,760.0$ & $1.56 \mathrm{E}-07$ & $9.78 \mathrm{E}-08$ & $2.49 \mathrm{E}-07$ & $1.31 \mathrm{E}-08$ & $4.12 \mathrm{E}-07$ & $1.12 \mathrm{E}-07$ \\
\hline 2010 & 1 & $10,301,760.0$ & $1.69 \mathrm{E}-07$ & $9.85 \mathrm{E}-08$ & $2.91 \mathrm{E}-07$ & $1.31 \mathrm{E}-08$ & 4.12E-07 & $1.12 \mathrm{E}-07$ \\
\hline 2011 & 3 & $10,459,440.0$ & $1.84 \mathrm{E}-07$ & $9.65 \mathrm{E}-08$ & $3.50 \mathrm{E}-07$ & 7.97E-08 & $6.22 \mathrm{E}-07$ & $2.57 E-07$ \\
\hline 2012 & 3 & $10,363,080.0$ & $2.00 \mathrm{E}-07$ & $9.31 \mathrm{E}-08$ & $4.28 \mathrm{E}-07$ & $8.03 E-08$ & $6.27 E-07$ & $2.59 \mathrm{E}-07$ \\
\hline Total & 32 & $154,675,320.0$ & & & & & & \\
\hline
\end{tabular}


Table 15. Plot data for industry-wide AOV SO trend, $>20$ demands per year. Figure 6

\begin{tabular}{|c|c|c|c|c|c|c|c|c|}
\hline \multirow[b]{2}{*}{$\begin{array}{c}\text { FYI } \\
\text { Source }\end{array}$} & \multirow[b]{2}{*}{ Failures } & \multirow[b]{2}{*}{ Hours } & \multicolumn{3}{|c|}{ Regression Curve Data Points } & \multicolumn{3}{|c|}{ Plot Trend Error Bar Points } \\
\hline & & & Mean & $\begin{array}{l}\text { Lower } \\
(5 \%)\end{array}$ & $\begin{array}{l}\text { Upper } \\
(95 \%)\end{array}$ & $\begin{array}{c}\text { Lower } \\
(5 \%)\end{array}$ & $\begin{array}{l}\text { Upper } \\
(95 \%) \\
\end{array}$ & Mean \\
\hline \multicolumn{2}{|c|}{ Update 2010} & & & & & 2.04E-09 & $4.49 \mathrm{E}-07$ & $1.31 \mathrm{E}-07$ \\
\hline 1998 & 3 & $7,507,320.0$ & & & & $9.13 \mathrm{E}-08$ & $7.13 \mathrm{E}-07$ & $2.95 \mathrm{E}-07$ \\
\hline 1999 & 3 & $7,533,600.0$ & & & & $9.11 \mathrm{E}-08$ & $7.11 \mathrm{E}-07$ & $2.94 \mathrm{E}-07$ \\
\hline 2000 & 0 & $7,551,120.0$ & & & & $1.65 \mathrm{E}-10$ & $3.28 \mathrm{E}-07$ & $4.20 \mathrm{E}-08$ \\
\hline 2001 & 3 & $7,454,760.0$ & & & & $9.17 \mathrm{E}-08$ & $7.16 \mathrm{E}-07$ & $2.96 \mathrm{E}-07$ \\
\hline 2002 & 1 & $7,507,320.0$ & & & & $1.48 \mathrm{E}-08$ & $4.66 \mathrm{E}-07$ & $1.26 \mathrm{E}-07$ \\
\hline 2003 & 0 & $7,472,280.0$ & $6.38 \mathrm{E}-08$ & $2.32 \mathrm{E}-08$ & $1.75 \mathrm{E}-07$ & $1.66 \mathrm{E}-10$ & $3.30 \mathrm{E}-07$ & $4.22 \mathrm{E}-08$ \\
\hline 2004 & 0 & $7,472,280.0$ & $6.89 \mathrm{E}-08$ & $2.93 \mathrm{E}-08$ & $1.62 \mathrm{E}-07$ & $1.66 \mathrm{E}-10$ & $3.30 \mathrm{E}-07$ & $4.22 \mathrm{E}-08$ \\
\hline 2005 & 1 & $7,481,040.0$ & $7.45 \mathrm{E}-08$ & $3.62 \mathrm{E}-08$ & $1.53 \mathrm{E}-07$ & $1.49 \mathrm{E}-08$ & 4.67E-07 & $1.27 \mathrm{E}-07$ \\
\hline 2006 & 1 & $7,446,000.0$ & $8.06 \mathrm{E}-08$ & 4.37E-08 & $1.49 \mathrm{E}-07$ & $1.49 \mathrm{E}-08$ & $4.69 E-07$ & $1.27 \mathrm{E}-07$ \\
\hline 2007 & 0 & $7,446,000.0$ & $8.71 \mathrm{E}-08$ & $5.04 \mathrm{E}-08$ & $1.51 \mathrm{E}-07$ & $1.66 \mathrm{E}-10$ & $3.31 \mathrm{E}-07$ & $4.23 \mathrm{E}-08$ \\
\hline 2008 & 2 & $7,463,520.0$ & $9.42 \mathrm{E}-08$ & $5.48 \mathrm{E}-08$ & $1.62 \mathrm{E}-07$ & $4.84 \mathrm{E}-08$ & $5.95 E-07$ & $2.11 \mathrm{E}-07$ \\
\hline 2009 & 2 & $7,446,000.0$ & $1.02 \mathrm{E}-07$ & $5.61 \mathrm{E}-08$ & $1.85 \mathrm{E}-07$ & $4.85 \mathrm{E}-08$ & $5.96 \mathrm{E}-07$ & $2.12 \mathrm{E}-07$ \\
\hline 2010 & 1 & $7,349,640.0$ & 1.10E-07 & $5.47 \mathrm{E}-08$ & $2.22 \mathrm{E}-07$ & $1.50 \mathrm{E}-08$ & $4.73 E-07$ & $1.28 \mathrm{E}-07$ \\
\hline 2011 & 0 & $7,367,160.0$ & 1.19E-07 & $5.19 \mathrm{E}-08$ & 2.73E-07 & $1.68 \mathrm{E}-10$ & $3.33 E-07$ & $4.26 \mathrm{E}-08$ \\
\hline 2012 & 1 & $7,253,280.0$ & $1.29 \mathrm{E}-07$ & $4.83 \mathrm{E}-08$ & $3.43 \mathrm{E}-07$ & $1.51 \mathrm{E}-08$ & $4.76 \mathrm{E}-07$ & $1.29 \mathrm{E}-07$ \\
\hline Total & 18 & $111,751,320.0$ & & & & & & \\
\hline
\end{tabular}

Table 16. Plot data for frequency (events per reactor year) of AOV operation demands with $\leq 20$ demands per year. Figure 7

\begin{tabular}{|c|c|c|c|c|c|c|c|c|}
\hline \multirow[b]{2}{*}{ FY } & \multirow[b]{2}{*}{ Demands } & \multirow[b]{2}{*}{$\begin{array}{c}\text { Reactor } \\
\text { Years }\end{array}$} & \multicolumn{3}{|c|}{ Regression Curve Data Points } & \multicolumn{3}{|c|}{ Plot Trend Error Bar Points } \\
\hline & & & Mean & $\begin{array}{c}\text { Lower } \\
(5 \%)\end{array}$ & $\begin{array}{l}\text { Upper } \\
\text { (95\%) }\end{array}$ & $\begin{array}{c}\text { Lower } \\
(5 \%)\end{array}$ & $\begin{array}{l}\text { Upper } \\
(95 \%)\end{array}$ & Mean \\
\hline 1998 & 8,284 & 87.0 & & & & $9.35 \mathrm{E}+01$ & $9.70 \mathrm{E}+01$ & $9.52 E+01$ \\
\hline 1999 & 8,371 & 87.0 & & & & $9.45 E+01$ & $9.80 \mathrm{E}+01$ & $9.62 E+01$ \\
\hline 2000 & 8,232 & 87.2 & & & & $9.27 E+01$ & $9.61 \mathrm{E}+01$ & $9.44 \mathrm{E}+01$ \\
\hline 2001 & 8,426 & 87.0 & & & & $9.51 E+01$ & $9.86 \mathrm{E}+01$ & $9.68 \mathrm{E}+01$ \\
\hline 2002 & 8,464 & 87.0 & & & & $9.56 \mathrm{E}+01$ & $9.90 \mathrm{E}+01$ & $9.73 E+01$ \\
\hline 2003 & 8,507 & 87.0 & $9.77 E+01$ & $9.46 \mathrm{E}+01$ & $1.01 \mathrm{E}+02$ & $9.60 \mathrm{E}+01$ & $9.95 \mathrm{E}+01$ & $9.78 \mathrm{E}+01$ \\
\hline 2004 & 8,592 & 87.2 & $9.69 \mathrm{E}+01$ & $9.44 \mathrm{E}+01$ & $9.95 \mathrm{E}+01$ & $9.68 \mathrm{E}+01$ & $1.00 \mathrm{E}+02$ & $9.85 E+01$ \\
\hline 2005 & 8,649 & 87.0 & $9.62 \mathrm{E}+01$ & $9.41 \mathrm{E}+01$ & $9.84 \mathrm{E}+01$ & $9.77 E+01$ & $1.01 \mathrm{E}+02$ & $9.94 \mathrm{E}+01$ \\
\hline 2006 & 8,053 & 87.0 & $9.55 \mathrm{E}+01$ & $9.37 E+01$ & $9.73 E+01$ & $9.09 E+01$ & $9.43 E+01$ & $9.26 \mathrm{E}+01$ \\
\hline 2007 & 8,096 & 87.0 & $9.48 \mathrm{E}+01$ & $9.32 \mathrm{E}+01$ & $9.64 \mathrm{E}+01$ & $9.14 \mathrm{E}+01$ & $9.48 \mathrm{E}+01$ & $9.31 E+01$ \\
\hline 2008 & 8,056 & 87.2 & $9.41 \mathrm{E}+01$ & $9.25 E+01$ & $9.57 \mathrm{E}+01$ & $9.07 E+01$ & $9.41 \mathrm{E}+01$ & $9.24 \mathrm{E}+01$ \\
\hline 2009 & 8,004 & 87.0 & $9.34 \mathrm{E}+01$ & $9.16 \mathrm{E}+01$ & $9.52 \mathrm{E}+01$ & $9.03 E+01$ & $9.37 \mathrm{E}+01$ & $9.20 \mathrm{E}+01$ \\
\hline 2010 & 8,137 & 87.0 & $9.27 \mathrm{E}+01$ & $9.06 \mathrm{E}+01$ & $9.48 \mathrm{E}+01$ & $9.18 \mathrm{E}+01$ & $9.53 E+01$ & $9.35 E+01$ \\
\hline 2011 & 8,025 & 87.0 & $9.20 \mathrm{E}+01$ & $8.95 E+01$ & $9.45 \mathrm{E}+01$ & $9.06 E+01$ & $9.39 \mathrm{E}+01$ & $9.22 E+01$ \\
\hline 2012 & 8,132 & 87.2 & $9.13 E+01$ & $8.84 \mathrm{E}+01$ & $9.43 E+01$ & $9.15 E+01$ & $9.49 \mathrm{E}+01$ & $9.32 E+01$ \\
\hline Total & 124,027 & $1,306.0$ & & & & & & \\
\hline
\end{tabular}


Table 17. Plot data for frequency (events per reactor year) of AOV operation demands with $>20$ demands per year. Figure 8

\begin{tabular}{ccccccccc}
\hline & & & \multicolumn{2}{c}{ Regression Curve Data Points } & \multicolumn{2}{c}{ Plot Trend Error Bar Points } \\
\cline { 6 - 9 } FY & Demands & $\begin{array}{c}\text { Reactor } \\
\text { Years }\end{array}$ & Mean & $\begin{array}{c}\text { Lower } \\
\mathbf{( 5 \% )}\end{array}$ & $\begin{array}{c}\text { Upper } \\
\mathbf{( 9 5 \% )}\end{array}$ & $\begin{array}{c}\text { Lower } \\
\mathbf{( 5 \% )}\end{array}$ & $\begin{array}{c}\text { Upper } \\
\mathbf{( 9 5 \% )}\end{array}$ & Mean \\
\hline 1998 & 26,652 & 88.0 & & & & $3.00 \mathrm{E}+02$ & $3.06 \mathrm{E}+02$ & $3.03 \mathrm{E}+02$ \\
\hline 1999 & 28,627 & 88.0 & & & & $3.22 \mathrm{E}+02$ & $3.28 \mathrm{E}+02$ & $3.25 \mathrm{E}+02$ \\
\hline 2000 & 27,879 & 88.2 & & & & $3.13 \mathrm{E}+02$ & $3.19 \mathrm{E}+02$ & $3.16 \mathrm{E}+02$ \\
\hline 2001 & 27,217 & 88.0 & & & & $3.06 \mathrm{E}+02$ & $3.12 \mathrm{E}+02$ & $3.09 \mathrm{E}+02$ \\
\hline 2002 & 27,533 & 88.0 & & & & $3.10 \mathrm{E}+02$ & $3.16 \mathrm{E}+02$ & $3.13 \mathrm{E}+02$ \\
\hline 2003 & 27,826 & 88.0 & $3.15 \mathrm{E}+02$ & $3.10 \mathrm{E}+02$ & $3.21 \mathrm{E}+02$ & $3.13 \mathrm{E}+02$ & $3.19 \mathrm{E}+02$ & $3.16 \mathrm{E}+02$ \\
\hline 2004 & 27,270 & 88.2 & $3.14 \mathrm{E}+02$ & $3.10 \mathrm{E}+02$ & $3.19 \mathrm{E}+02$ & $3.06 \mathrm{E}+02$ & $3.12 \mathrm{E}+02$ & $3.09 \mathrm{E}+02$ \\
\hline 2005 & 27,600 & 88.0 & $3.13 \mathrm{E}+02$ & $3.10 \mathrm{E}+02$ & $3.17 \mathrm{E}+02$ & $3.11 \mathrm{E}+02$ & $3.17 \mathrm{E}+02$ & $3.14 \mathrm{E}+02$ \\
\hline 2006 & 27,333 & 88.0 & $3.12 \mathrm{E}+02$ & $3.09 \mathrm{E}+02$ & $3.15 \mathrm{E}+02$ & $3.08 \mathrm{E}+02$ & $3.14 \mathrm{E}+02$ & $3.11 \mathrm{E}+02$ \\
\hline 2007 & 27,892 & 88.0 & $3.11 \mathrm{E}+02$ & $3.08 \mathrm{E}+02$ & $3.14 \mathrm{E}+02$ & $3.14 \mathrm{E}+02$ & $3.20 \mathrm{E}+02$ & $3.17 \mathrm{E}+02$ \\
\hline 2008 & 27,759 & 88.2 & $3.10 \mathrm{E}+02$ & $3.07 \mathrm{E}+02$ & $3.13 \mathrm{E}+02$ & $3.11 \mathrm{E}+02$ & $3.18 \mathrm{E}+02$ & $3.15 \mathrm{E}+02$ \\
\hline 2009 & 27,107 & 88.0 & $3.09 \mathrm{E}+02$ & $3.06 \mathrm{E}+02$ & $3.12 \mathrm{E}+02$ & $3.05 \mathrm{E}+02$ & $3.11 \mathrm{E}+02$ & $3.08 \mathrm{E}+02$ \\
\hline 2010 & 27,052 & 88.0 & $3.08 \mathrm{E}+02$ & $3.04 \mathrm{E}+02$ & $3.12 \mathrm{E}+02$ & $3.04 \mathrm{E}+02$ & $3.11 \mathrm{E}+02$ & $3.07 \mathrm{E}+02$ \\
\hline 2011 & 27,049 & 88.0 & $3.07 \mathrm{E}+02$ & $3.02 \mathrm{E}+02$ & $3.11 \mathrm{E}+02$ & $3.04 \mathrm{E}+02$ & $3.10 \mathrm{E}+02$ & $3.07 \mathrm{E}+02$ \\
\hline 2012 & 26,662 & 88.2 & $3.06 \mathrm{E}+02$ & $3.01 \mathrm{E}+02$ & $3.11 \mathrm{E}+02$ & $2.99 \mathrm{E}+02$ & $3.05 \mathrm{E}+02$ & $3.02 \mathrm{E}+02$ \\
\hline Total & 411,456 & $1,321.0$ & & & & & & \\
\hline
\end{tabular}

Table 18. Plot data for frequency (events per reactor year) of AOV FTOC events with $\leq 20$ demands per year. Figure 9

\begin{tabular}{ccccccccc}
\hline & & & \multicolumn{2}{c}{ Regression Curve Data Points } & \multicolumn{2}{c}{ Plot Trend Error Bar Points } \\
\cline { 6 - 9 } FY & Failures & $\begin{array}{c}\text { Reactor } \\
\text { Years }\end{array}$ & Mean & $\begin{array}{c}\text { Lower } \\
\mathbf{( 5 \% )}\end{array}$ & $\begin{array}{c}\text { Upper } \\
\mathbf{( 9 5 \% )}\end{array}$ & $\begin{array}{c}\text { Lower } \\
\mathbf{( 5 \% )}\end{array}$ & $\begin{array}{c}\text { Upper } \\
\mathbf{( 9 5 \% )}\end{array}$ & Mean \\
\hline 1998 & 10 & 87.0 & & & & $6.21 \mathrm{E}-02$ & $1.88 \mathrm{E}-01$ & $1.12 \mathrm{E}-01$ \\
1999 & 8 & 87.0 & & & & $4.64 \mathrm{E}-02$ & $1.61 \mathrm{E}-01$ & $9.10 \mathrm{E}-02$ \\
\hline 2000 & 5 & 87.2 & & & & $2.44 \mathrm{E}-02$ & $1.19 \mathrm{E}-01$ & $5.88 \mathrm{E}-02$ \\
\hline 2001 & 8 & 87.0 & & & & $4.64 \mathrm{E}-02$ & $1.61 \mathrm{E}-01$ & $9.10 \mathrm{E}-02$ \\
\hline 2002 & 7 & 87.0 & & & & $3.89 \mathrm{E}-02$ & $1.48 \mathrm{E}-01$ & $8.03 \mathrm{E}-02$ \\
2003 & 9 & 87.0 & $8.13 \mathrm{E}-02$ & $4.80 \mathrm{E}-02$ & $1.38 \mathrm{E}-01$ & $5.42 \mathrm{E}-02$ & $1.75 \mathrm{E}-01$ & $1.02 \mathrm{E}-01$ \\
\hline 2004 & 6 & 87.2 & $7.95 \mathrm{E}-02$ & $5.09 \mathrm{E}-02$ & $1.24 \mathrm{E}-01$ & $3.15 \mathrm{E}-02$ & $1.34 \mathrm{E}-01$ & $6.94 \mathrm{E}-02$ \\
2005 & 5 & 87.0 & $7.78 \mathrm{E}-02$ & $5.35 \mathrm{E}-02$ & $1.13 \mathrm{E}-01$ & $2.45 \mathrm{E}-02$ & $1.20 \mathrm{E}-01$ & $5.89 \mathrm{E}-02$ \\
\hline 2006 & 8 & 87.0 & $7.61 \mathrm{E}-02$ & $5.52 \mathrm{E}-02$ & $1.05 \mathrm{E}-01$ & $4.64 \mathrm{E}-02$ & $1.61 \mathrm{E}-01$ & $9.10 \mathrm{E}-02$ \\
\hline 2007 & 6 & 87.0 & $7.44 \mathrm{E}-02$ & $5.56 \mathrm{E}-02$ & $9.98 \mathrm{E}-02$ & $3.16 \mathrm{E}-02$ & $1.34 \mathrm{E}-01$ & $6.96 \mathrm{E}-02$ \\
\hline 2008 & 6 & 87.2 & $7.28 \mathrm{E}-02$ & $5.41 \mathrm{E}-02$ & $9.81 \mathrm{E}-02$ & $3.15 \mathrm{E}-02$ & $1.34 \mathrm{E}-01$ & $6.94 \mathrm{E}-02$ \\
\hline 2009 & 5 & 87.0 & $7.12 \mathrm{E}-02$ & $5.09 \mathrm{E}-02$ & $9.96 \mathrm{E}-02$ & $2.45 \mathrm{E}-02$ & $1.20 \mathrm{E}-01$ & $5.89 \mathrm{E}-02$ \\
\hline 2010 & 7 & 87.0 & $6.97 \mathrm{E}-02$ & $4.69 \mathrm{E}-02$ & $1.04 \mathrm{E}-01$ & $3.89 \mathrm{E}-02$ & $1.48 \mathrm{E}-01$ & $8.03 \mathrm{E}-02$ \\
\hline 2011 & 13 & 87.0 & $6.82 \mathrm{E}-02$ & $4.26 \mathrm{E}-02$ & $1.09 \mathrm{E}-01$ & $8.65 \mathrm{E}-02$ & $2.28 \mathrm{E}-01$ & $1.45 \mathrm{E}-01$ \\
\hline 2012 & 3 & 87.2 & $6.67 \mathrm{E}-02$ & $3.83 \mathrm{E}-02$ & $1.16 \mathrm{E}-01$ & $1.16 \mathrm{E}-02$ & $9.04 \mathrm{E}-02$ & $3.74 \mathrm{E}-02$ \\
\hline Total & 106 & $1,306.0$ & & & & & & \\
\hline
\end{tabular}


Table 19. Plot data for frequency (events per reactor year) of AOV FTOC events with $>20$ demands per year. Figure 10

\begin{tabular}{ccccccccc}
\hline & & & \multicolumn{2}{c}{ Regression Curve Data Points } & \multicolumn{2}{c}{ Plot Trend Error Bar Points } \\
\cline { 6 - 9 } FY & Failures & $\begin{array}{c}\text { Reactor } \\
\text { Years }\end{array}$ & Mean & $\begin{array}{c}\text { Lower } \\
\mathbf{( 5 \% )}\end{array}$ & $\begin{array}{c}\text { Upper } \\
\mathbf{( 9 5 \% )}\end{array}$ & $\begin{array}{c}\text { Lower } \\
\mathbf{( 5 \% )}\end{array}$ & $\begin{array}{c}\text { Upper } \\
\mathbf{( 9 5 \% )}\end{array}$ & Mean \\
\hline 1998 & 12 & 88.0 & & & & $7.69 \mathrm{E}-02$ & $2.11 \mathrm{E}-01$ & $1.32 \mathrm{E}-01$ \\
\hline 1999 & 10 & 88.0 & & & & $6.10 \mathrm{E}-02$ & $1.85 \mathrm{E}-01$ & $1.10 \mathrm{E}-01$ \\
\hline 2000 & 7 & 88.2 & & & & $3.81 \mathrm{E}-02$ & $1.45 \mathrm{E}-01$ & $7.87 \mathrm{E}-02$ \\
\hline 2001 & 11 & 88.0 & & & & $6.89 \mathrm{E}-02$ & $1.98 \mathrm{E}-01$ & $1.21 \mathrm{E}-01$ \\
\hline 2002 & 5 & 88.0 & & & & $2.41 \mathrm{E}-02$ & $1.18 \mathrm{E}-01$ & $5.79 \mathrm{E}-02$ \\
\hline 2003 & 7 & 88.0 & $7.44 \mathrm{E}-02$ & $4.28 \mathrm{E}-02$ & $1.29 \mathrm{E}-01$ & $3.82 \mathrm{E}-02$ & $1.45 \mathrm{E}-01$ & $7.89 \mathrm{E}-02$ \\
\hline 2004 & 8 & 88.2 & $7.27 \mathrm{E}-02$ & $4.55 \mathrm{E}-02$ & $1.16 \mathrm{E}-01$ & $4.55 \mathrm{E}-02$ & $1.58 \mathrm{E}-01$ & $8.92 \mathrm{E}-02$ \\
\hline 2005 & 6 & 88.0 & $7.10 \mathrm{E}-02$ & $4.79 \mathrm{E}-02$ & $1.05 \mathrm{E}-01$ & $3.10 \mathrm{E}-02$ & $1.31 \mathrm{E}-01$ & $6.84 \mathrm{E}-02$ \\
\hline 2006 & 7 & 88.0 & $6.94 \mathrm{E}-02$ & $4.95 \mathrm{E}-02$ & $9.71 \mathrm{E}-02$ & $3.82 \mathrm{E}-02$ & $1.45 \mathrm{E}-01$ & $7.89 \mathrm{E}-02$ \\
\hline 2007 & 2 & 88.0 & $6.78 \mathrm{E}-02$ & $4.99 \mathrm{E}-02$ & $9.22 \mathrm{E}-02$ & $6.03 \mathrm{E}-03$ & $7.40 \mathrm{E}-02$ & $2.63 \mathrm{E}-02$ \\
\hline 2008 & 7 & 88.2 & $6.62 \mathrm{E}-02$ & $4.84 \mathrm{E}-02$ & $9.06 \mathrm{E}-02$ & $3.81 \mathrm{E}-02$ & $1.45 \mathrm{E}-01$ & $7.87 \mathrm{E}-02$ \\
\hline 2009 & 7 & 88.0 & $6.47 \mathrm{E}-02$ & $4.55 \mathrm{E}-02$ & $9.21 \mathrm{E}-02$ & $3.82 \mathrm{E}-02$ & $1.45 \mathrm{E}-01$ & $7.89 \mathrm{E}-02$ \\
\hline 2010 & 7 & 88.0 & $6.32 \mathrm{E}-02$ & $4.17 \mathrm{E}-02$ & $9.59 \mathrm{E}-02$ & $3.82 \mathrm{E}-02$ & $1.45 \mathrm{E}-01$ & $7.89 \mathrm{E}-02$ \\
\hline 2011 & 7 & 88.0 & $6.18 \mathrm{E}-02$ & $3.77 \mathrm{E}-02$ & $1.01 \mathrm{E}-01$ & $3.82 \mathrm{E}-02$ & $1.45 \mathrm{E}-01$ & $7.89 \mathrm{E}-02$ \\
\hline 2012 & 4 & 88.2 & $6.04 \mathrm{E}-02$ & $3.38 \mathrm{E}-02$ & $1.08 \mathrm{E}-01$ & $1.74 \mathrm{E}-02$ & $1.03 \mathrm{E}-01$ & $4.72 \mathrm{E}-02$ \\
\hline Total & 107 & $1,321.0$ & & & & & & \\
\hline
\end{tabular}

Table 20. Plot data for frequency (events per reactor year) of AOV FTOP events with $\leq 20$ demands per year.

Figure 9

\begin{tabular}{|c|c|c|c|c|c|c|c|c|}
\hline \multirow[b]{2}{*}{ FY } & \multirow[b]{2}{*}{ Failures } & \multirow[b]{2}{*}{$\begin{array}{c}\text { Reactor } \\
\text { Years }\end{array}$} & \multicolumn{3}{|c|}{ Regression Curve Data Points } & \multicolumn{3}{|c|}{ Plot Trend Error Bar Points } \\
\hline & & & Mean & $\begin{array}{c}\text { Lower } \\
(5 \%)\end{array}$ & $\begin{array}{l}\text { Upper } \\
(95 \%)\end{array}$ & $\begin{array}{c}\text { Lower } \\
(5 \%)\end{array}$ & $\begin{array}{l}\text { Upper } \\
(95 \%)\end{array}$ & Mean \\
\hline 1998 & 0 & 87.0 & & & & $1.48 \mathrm{E}-05$ & $2.94 \mathrm{E}-02$ & $3.76 \mathrm{E}-03$ \\
\hline 1999 & 3 & 87.0 & & & & 8.16E-03 & 6.37E-02 & 2.64E-02 \\
\hline 2000 & 1 & 87.2 & & & & $1.32 \mathrm{E}-03$ & 4.16E-02 & $1.13 \mathrm{E}-02$ \\
\hline 2001 & 3 & 87.0 & & & & $8.16 \mathrm{E}-03$ & $6.37 \mathrm{E}-02$ & $2.64 \mathrm{E}-02$ \\
\hline 2002 & 2 & 87.0 & & & & $4.31 \mathrm{E}-03$ & $5.30 \mathrm{E}-02$ & $1.88 \mathrm{E}-02$ \\
\hline 2003 & 1 & 87.0 & $6.82 \mathrm{E}-03$ & $2.65 \mathrm{E}-03$ & $1.76 \mathrm{E}-02$ & $1.32 \mathrm{E}-03$ & 4.17E-02 & $1.13 \mathrm{E}-02$ \\
\hline 2004 & 0 & 87.2 & $7.26 \mathrm{E}-03$ & $3.24 \mathrm{E}-03$ & $1.62 \mathrm{E}-02$ & $1.48 \mathrm{E}-05$ & $2.94 \mathrm{E}-02$ & $3.76 \mathrm{E}-03$ \\
\hline 2005 & 2 & 87.0 & $7.71 \mathrm{E}-03$ & $3.92 \mathrm{E}-03$ & $1.52 \mathrm{E}-02$ & $4.31 \mathrm{E}-03$ & $5.30 \mathrm{E}-02$ & $1.88 \mathrm{E}-02$ \\
\hline 2006 & 0 & 87.0 & $8.20 E-03$ & 4.62E-03 & $1.46 \mathrm{E}-02$ & $1.48 \mathrm{E}-05$ & $2.94 \mathrm{E}-02$ & $3.76 \mathrm{E}-03$ \\
\hline 2007 & 0 & 87.0 & $8.72 \mathrm{E}-03$ & $5.22 \mathrm{E}-03$ & $1.46 \mathrm{E}-02$ & $1.48 \mathrm{E}-05$ & $2.94 \mathrm{E}-02$ & $3.76 \mathrm{E}-03$ \\
\hline 2008 & 2 & 87.2 & $9.28 \mathrm{E}-03$ & $5.59 \mathrm{E}-03$ & $1.54 \mathrm{E}-02$ & 4.30E-03 & $5.29 \mathrm{E}-02$ & $1.88 \mathrm{E}-02$ \\
\hline 2009 & 1 & 87.0 & $9.86 \mathrm{E}-03$ & $5.65 \mathrm{E}-03$ & 1.72E-02 & $1.32 \mathrm{E}-03$ & 4.17E-02 & 1.13E-02 \\
\hline 2010 & 1 & 87.0 & $1.05 E-02$ & $5.47 \mathrm{E}-03$ & $2.01 \mathrm{E}-02$ & $1.32 \mathrm{E}-03$ & 4.17E-02 & $1.13 \mathrm{E}-02$ \\
\hline 2011 & 1 & 87.0 & $1.12 \mathrm{E}-02$ & $5.14 \mathrm{E}-03$ & $2.42 \mathrm{E}-02$ & $1.32 \mathrm{E}-03$ & 4.17E-02 & 1.13E-02 \\
\hline 2012 & 1 & 87.2 & $1.19 \mathrm{E}-02$ & $4.75 \mathrm{E}-03$ & $2.96 \mathrm{E}-02$ & $1.32 \mathrm{E}-03$ & 4.16E-02 & $1.13 \mathrm{E}-02$ \\
\hline Total & 18 & $1,306.0$ & & & & & & \\
\hline
\end{tabular}


Table 21. Plot data for frequency (events per reactor year) of AOV FTOP events with $>20$ demands per year. Figure 10

\begin{tabular}{ccccccccc}
\hline & & & \multicolumn{2}{c}{ Regression Curve Data Points } & \multicolumn{2}{c}{ Plot Trend Error Bar Points } \\
\cline { 6 - 9 } FY & Failures & $\begin{array}{c}\text { Reactor } \\
\text { Years }\end{array}$ & Mean & $\begin{array}{c}\text { Lower } \\
\mathbf{( 5 \% )}\end{array}$ & $\begin{array}{c}\text { Upper } \\
\mathbf{( 9 5 \% )}\end{array}$ & $\begin{array}{c}\text { Lower } \\
\mathbf{( 5 \% )}\end{array}$ & $\begin{array}{c}\text { Upper } \\
\mathbf{( 9 5 \% )}\end{array}$ & Mean \\
\hline 1998 & 3 & 88.0 & & & & $1.04 \mathrm{E}-02$ & $8.09 \mathrm{E}-02$ & $3.35 \mathrm{E}-02$ \\
\hline 1999 & 3 & 88.0 & & & & $1.04 \mathrm{E}-02$ & $8.09 \mathrm{E}-02$ & $3.35 \mathrm{E}-02$ \\
\hline 2000 & 6 & 88.2 & & & & $2.81 \mathrm{E}-02$ & $1.19 \mathrm{E}-01$ & $6.20 \mathrm{E}-02$ \\
\hline 2001 & 2 & 88.0 & & & & $5.47 \mathrm{E}-03$ & $6.72 \mathrm{E}-02$ & $2.39 \mathrm{E}-02$ \\
\hline 2002 & 2 & 88.0 & & & & $5.47 \mathrm{E}-03$ & $6.72 \mathrm{E}-02$ & $2.39 \mathrm{E}-02$ \\
\hline 2003 & 3 & 88.0 & $3.09 \mathrm{E}-02$ & $2.11 \mathrm{E}-02$ & $4.52 \mathrm{E}-02$ & $1.04 \mathrm{E}-02$ & $8.09 \mathrm{E}-02$ & $3.35 \mathrm{E}-02$ \\
\hline 2004 & 2 & 88.2 & $3.04 \mathrm{E}-02$ & $2.20 \mathrm{E}-02$ & $4.20 \mathrm{E}-02$ & $5.46 \mathrm{E}-03$ & $6.71 \mathrm{E}-02$ & $2.38 \mathrm{E}-02$ \\
\hline 2005 & 4 & 88.0 & $2.99 \mathrm{E}-02$ & $2.28 \mathrm{E}-02$ & $3.92 \mathrm{E}-02$ & $1.59 \mathrm{E}-02$ & $9.40 \mathrm{E}-02$ & $4.30 \mathrm{E}-02$ \\
\hline 2006 & 2 & 88.0 & $2.94 \mathrm{E}-02$ & $2.34 \mathrm{E}-02$ & $3.71 \mathrm{E}-02$ & $5.47 \mathrm{E}-03$ & $6.72 \mathrm{E}-02$ & $2.39 \mathrm{E}-02$ \\
\hline 2007 & 2 & 88.0 & $2.90 \mathrm{E}-02$ & $2.35 \mathrm{E}-02$ & $3.57 \mathrm{E}-02$ & $5.47 \mathrm{E}-03$ & $6.72 \mathrm{E}-02$ & $2.39 \mathrm{E}-02$ \\
\hline 2008 & 3 & 88.2 & $2.85 \mathrm{E}-02$ & $2.31 \mathrm{E}-02$ & $3.52 \mathrm{E}-02$ & $1.03 \mathrm{E}-02$ & $8.07 \mathrm{E}-02$ & $3.34 \mathrm{E}-02$ \\
\hline 2009 & 2 & 88.0 & $2.80 \mathrm{E}-02$ & $2.21 \mathrm{E}-02$ & $3.55 \mathrm{E}-02$ & $5.47 \mathrm{E}-03$ & $6.72 \mathrm{E}-02$ & $2.39 \mathrm{E}-02$ \\
\hline 2010 & 4 & 88.0 & $2.76 \mathrm{E}-02$ & $2.09 \mathrm{E}-02$ & $3.65 \mathrm{E}-02$ & $1.59 \mathrm{E}-02$ & $9.40 \mathrm{E}-02$ & $4.30 \mathrm{E}-02$ \\
\hline 2011 & 2 & 88.0 & $2.71 \mathrm{E}-02$ & $1.95 \mathrm{E}-02$ & $3.78 \mathrm{E}-02$ & $5.47 \mathrm{E}-03$ & $6.72 \mathrm{E}-02$ & $2.39 \mathrm{E}-02$ \\
\hline 2012 & 2 & 88.2 & $2.67 \mathrm{E}-02$ & $1.81 \mathrm{E}-02$ & $3.95 \mathrm{E}-02$ & $5.46 \mathrm{E}-03$ & $6.71 \mathrm{E}-02$ & $2.38 \mathrm{E}-02$ \\
\hline Total & 42 & $1,321.0$ & & & & & & \\
\hline
\end{tabular}

Table 22. Plot data for frequency (events per reactor year) of AOV SO events $\leq 20$ demands per year. Figure 13

\begin{tabular}{ccccccccc}
\hline & & & \multicolumn{2}{c}{ Regression Curve Data Points } & \multicolumn{2}{c}{ Plot Trend Error Bar Points } \\
\cline { 6 - 9 } FY & Failures & $\begin{array}{c}\text { Reactor } \\
\text { Years }\end{array}$ & Mean & $\begin{array}{c}\text { Lower } \\
\mathbf{( 5 \% )}\end{array}$ & $\begin{array}{c}\text { Upper } \\
\mathbf{( 9 5 \% )}\end{array}$ & $\begin{array}{c}\text { Lower } \\
\mathbf{( 5 \% )}\end{array}$ & $\begin{array}{c}\text { Upper } \\
\mathbf{( 9 5 \% )}\end{array}$ & Mean \\
\hline 1998 & 0 & 87.0 & & & & $1.73 \mathrm{E}-05$ & $3.45 \mathrm{E}-02$ & $4.41 \mathrm{E}-03$ \\
\hline 1999 & 6 & 87.0 & & & & $2.60 \mathrm{E}-02$ & $1.10 \mathrm{E}-01$ & $5.73 \mathrm{E}-02$ \\
\hline 2000 & 1 & 87.2 & & & & $1.55 \mathrm{E}-03$ & $4.87 \mathrm{E}-02$ & $1.32 \mathrm{E}-02$ \\
\hline 2001 & 1 & 87.0 & & & & $1.55 \mathrm{E}-03$ & $4.88 \mathrm{E}-02$ & $1.32 \mathrm{E}-02$ \\
\hline 2002 & 8 & 87.0 & & & & $3.82 \mathrm{E}-02$ & $1.33 \mathrm{E}-01$ & $7.50 \mathrm{E}-02$ \\
\hline 2003 & 2 & 87.0 & $1.13 \mathrm{E}-02$ & $4.86 \mathrm{E}-03$ & $2.63 \mathrm{E}-02$ & $5.05 \mathrm{E}-03$ & $6.20 \mathrm{E}-02$ & $2.20 \mathrm{E}-02$ \\
\hline 2004 & 1 & 87.2 & $1.23 \mathrm{E}-02$ & $5.98 \mathrm{E}-03$ & $2.52 \mathrm{E}-02$ & $1.55 \mathrm{E}-03$ & $4.87 \mathrm{E}-02$ & $1.32 \mathrm{E}-02$ \\
\hline 2005 & 1 & 87.0 & $1.33 \mathrm{E}-02$ & $7.27 \mathrm{E}-03$ & $2.44 \mathrm{E}-02$ & $1.55 \mathrm{E}-03$ & $4.88 \mathrm{E}-02$ & $1.32 \mathrm{E}-02$ \\
\hline 2006 & 0 & 87.0 & $1.45 \mathrm{E}-02$ & $8.67 \mathrm{E}-03$ & $2.41 \mathrm{E}-02$ & $1.73 \mathrm{E}-05$ & $3.45 \mathrm{E}-02$ & $4.41 \mathrm{E}-03$ \\
\hline 2007 & 2 & 87.0 & $1.57 \mathrm{E}-02$ & $1.00 \mathrm{E}-02$ & $2.46 \mathrm{E}-02$ & $5.05 \mathrm{E}-03$ & $6.20 \mathrm{E}-02$ & $2.20 \mathrm{E}-02$ \\
\hline 2008 & 2 & 87.2 & $1.71 \mathrm{E}-02$ & $1.11 \mathrm{E}-02$ & $2.63 \mathrm{E}-02$ & $5.04 \mathrm{E}-03$ & $6.19 \mathrm{E}-02$ & $2.20 \mathrm{E}-02$ \\
\hline 2009 & 1 & 87.0 & $1.85 \mathrm{E}-02$ & $1.16 \mathrm{E}-02$ & $2.95 \mathrm{E}-02$ & $1.55 \mathrm{E}-03$ & $4.88 \mathrm{E}-02$ & $1.32 \mathrm{E}-02$ \\
\hline 2010 & 1 & 87.0 & $2.01 \mathrm{E}-02$ & $1.17 \mathrm{E}-02$ & $3.46 \mathrm{E}-02$ & $1.55 \mathrm{E}-03$ & $4.88 \mathrm{E}-02$ & $1.32 \mathrm{E}-02$ \\
\hline 2011 & 3 & 87.0 & $2.18 \mathrm{E}-02$ & $1.15 \mathrm{E}-02$ & $4.16 \mathrm{E}-02$ & $9.56 \mathrm{E}-03$ & $7.46 \mathrm{E}-02$ & $3.09 \mathrm{E}-02$ \\
\hline 2012 & 3 & 87.2 & $2.37 \mathrm{E}-02$ & $1.11 \mathrm{E}-02$ & $5.08 \mathrm{E}-02$ & $9.54 \mathrm{E}-03$ & $7.45 \mathrm{E}-02$ & $3.08 \mathrm{E}-02$ \\
\hline Total & 32 & $1,306.0$ & & & & & & \\
\hline
\end{tabular}


Table 23. Plot data for frequency (events per reactor year) of AOV SO events $>20$ demands per year. Figure 14

\begin{tabular}{ccccccccc} 
& & & \multicolumn{2}{c}{ Regression Curve Data Points } & \multicolumn{2}{c}{ Plot Trend Error Bar Points } \\
\cline { 6 - 9 } FY & Failures & $\begin{array}{c}\text { Reactor } \\
\text { Years }\end{array}$ & Mean & $\begin{array}{c}\text { Lower } \\
\mathbf{( 5 \% )}\end{array}$ & $\begin{array}{c}\text { Upper } \\
\mathbf{( 9 5 \% )}\end{array}$ & $\begin{array}{c}\text { Lower } \\
\mathbf{( 5 \% )}\end{array}$ & $\begin{array}{c}\text { Upper } \\
\mathbf{( 9 5 \% )}\end{array}$ & Mean \\
\hline 1998 & 3 & 88.0 & & & & $7.75 \mathrm{E}-03$ & $6.05 \mathrm{E}-02$ & $2.50 \mathrm{E}-02$ \\
\hline 1999 & 3 & 88.0 & & & & $7.75 \mathrm{E}-03$ & $6.05 \mathrm{E}-02$ & $2.50 \mathrm{E}-02$ \\
\hline 2000 & 0 & 88.2 & & & & $1.40 \mathrm{E}-05$ & $2.79 \mathrm{E}-02$ & $3.57 \mathrm{E}-03$ \\
\hline 2001 & 3 & 88.0 & & & & $7.75 \mathrm{E}-03$ & $6.05 \mathrm{E}-02$ & $2.50 \mathrm{E}-02$ \\
\hline 2002 & 1 & 88.0 & & & & $1.26 \mathrm{E}-03$ & $3.96 \mathrm{E}-02$ & $1.07 \mathrm{E}-02$ \\
\hline 2003 & 0 & 88.0 & $5.41 \mathrm{E}-03$ & $1.97 \mathrm{E}-03$ & $1.49 \mathrm{E}-02$ & $1.41 \mathrm{E}-05$ & $2.79 \mathrm{E}-02$ & $3.58 \mathrm{E}-03$ \\
\hline 2004 & 0 & 88.2 & $5.84 \mathrm{E}-03$ & $2.48 \mathrm{E}-03$ & $1.38 \mathrm{E}-02$ & $1.40 \mathrm{E}-05$ & $2.79 \mathrm{E}-02$ & $3.57 \mathrm{E}-03$ \\
\hline 2005 & 1 & 88.0 & $6.31 \mathrm{E}-03$ & $3.06 \mathrm{E}-03$ & $1.30 \mathrm{E}-02$ & $1.26 \mathrm{E}-03$ & $3.96 \mathrm{E}-02$ & $1.07 \mathrm{E}-02$ \\
\hline 2006 & 1 & 88.0 & $6.81 \mathrm{E}-03$ & $3.68 \mathrm{E}-03$ & $1.26 \mathrm{E}-02$ & $1.26 \mathrm{E}-03$ & $3.96 \mathrm{E}-02$ & $1.07 \mathrm{E}-02$ \\
\hline 2007 & 0 & 88.0 & $7.35 \mathrm{E}-03$ & $4.25 \mathrm{E}-03$ & $1.27 \mathrm{E}-02$ & $1.41 \mathrm{E}-05$ & $2.79 \mathrm{E}-02$ & $3.58 \mathrm{E}-03$ \\
\hline 2008 & 2 & 88.2 & $7.93 \mathrm{E}-03$ & $4.61 \mathrm{E}-03$ & $1.36 \mathrm{E}-02$ & $4.09 \mathrm{E}-03$ & $5.02 \mathrm{E}-02$ & $1.79 \mathrm{E}-02$ \\
\hline 2009 & 2 & 88.0 & $8.56 \mathrm{E}-03$ & $4.71 \mathrm{E}-03$ & $1.56 \mathrm{E}-02$ & $4.10 \mathrm{E}-03$ & $5.03 \mathrm{E}-02$ & $1.79 \mathrm{E}-02$ \\
\hline 2010 & 1 & 88.0 & $9.24 \mathrm{E}-03$ & $4.59 \mathrm{E}-03$ & $1.86 \mathrm{E}-02$ & $1.26 \mathrm{E}-03$ & $3.96 \mathrm{E}-02$ & $1.07 \mathrm{E}-02$ \\
\hline 2011 & 0 & 88.0 & $9.97 \mathrm{E}-03$ & $4.34 \mathrm{E}-03$ & $2.29 \mathrm{E}-02$ & $1.41 \mathrm{E}-05$ & $2.79 \mathrm{E}-02$ & $3.58 \mathrm{E}-03$ \\
\hline 2012 & 1 & 88.2 & $1.08 \mathrm{E}-02$ & $4.03 \mathrm{E}-03$ & $2.87 \mathrm{E}-02$ & $1.26 \mathrm{E}-03$ & $3.95 \mathrm{E}-02$ & $1.07 \mathrm{E}-02$ \\
\hline Total & 18 & $1,321.0$ & & & & & & \\
\hline
\end{tabular}




\section{REFERENCES}

1. Nuclear Regulatory Commission, Component Reliability Data Sheets Update 2010, January 2012, http://nrcoe.inl.gov/resultsdb/publicdocs/AvgPerf/ComponentReliabilityDataSheets2010.pdf

2. S.A. Eide et al., Industry-Average Performance for Components and Initiating Events at U.S. Commercial Nuclear Power Plants, Nuclear Regulatory Commission, NUREG/CR-6928, February 2007. 
